Doc. dr. sc. Tomislav Jakšić ${ }^{1}$

\title{
POJAM ORGANIZACIJE ZA KOLEKTIVNO OSTVARIVANJE PRAVA I NEOVISNOG UPRAVLJAČKOG SUBJEKTA
}

\author{
$U D K: 347.78$ \\ DOI: $10.31141 /$ zrpfs.2021.58.141.785 \\ Izvorni znanstveni rad \\ Primljeno: 10. veljače 2021.
}

\begin{abstract}
Kako bi se neka osoba kvalificirala kao organizacija za kolektivno ostvarivanje prava mora: 1) ostvarivati autorska i srodna prava, 2) kolektivno ostvarivati takva prava za više nositelja prava (npr. autora), 3) ostvarivati prava za zajedničku korist (račun) nositelja prava te 4) kolektivno ostvarivati takva prava kao jedinu ili glavnu svrhu takve organizacije. Pored tih općih uvjeta, organizacija za kolektivno ostvarivanje prava mora ispuniti i dva posebna uvjeta: 1) pripadnost ili potpadanje pod kontrolu svojih članova (nositelja prava ili osoba koje ih zastupaju) te 2) ustrojenost organizacije na neprofitnoj osnovi. S druge strane, neovisni upravljački subjekt, kao i organizacija za kolektivno ostvarivanje prava, mora ispuniti prva četiri opća uvjeta, ali i dva posebna uvjeta: 1) ne smije pripadati u cijelosti niti djelomično članovima (nositeljima prava ili osobama koje ih zastupaju), a ne smije biti niti pod njihovom izravnom ili neizravnom kontrolom, a 2) poslovanje organizacije pritom mora biti usmjereno na ostvarivanje dobiti. Rad pritom analizira predmetne uvjete ponajprije s ciljem jasnog razgraničenja organizacije za kolektivno ostvarivanje prava i neovisnog upravljačkog subjekta, a potom i osoba koje ne obavljaju djelatnost kolektivnog ostvarivanja prava od osoba koje obavljaju tu djelatnost. Takva su razgraničenja važna i radi određivanja razine nadzora nad tim organizacijama jer svaka organizacija potpada pod različitu razinu nadzora od strane Državnog zavoda za intelektualno vlasništvo. Pored navedenih uvjeta, u radu se analiziraju i odgovarajuće odredbe nacrta novog prijedloga Zakona o autorskim i srodnim pravima.
\end{abstract}

Ključne riječi: kolektivno ostvarivanje prava, organizacija za kolektivno ostvarivanje prava, neovisni upravljački subjekt, autorsko pravo, nositelj prava

\section{UVOD}

Kao rezultat usklađivanja s europskom pravnom stečevinom, izmjenama i dopunama Zakona o autorskom pravu i srodnim pravima (dalje: ZAPSP) iz 2017., u hrvatsko pravo uveden je novi način kolektivnog ostvarivanja prava pored organizacije za kolektivno ostvarivanje prava. ${ }^{2}$ Ostvarivanje i zaštita autorskih i srodnih prava nezamislivi su bez organizacija koje obavljaju djelatnost kolektivnog

1 Dr. sc. Tomislav Jakšić, docent na Pravnom fakultetu Sveučilišta u Zagrebu.

2 Tako vidi Zakon o autorskom pravu i srodnim pravima, Narodne novine br. 167/03, 79/07, 80/11, $125 / 11,141 / 13,127 / 14,62 / 17,96 / 18$. 
ostvarivanja prava. Takvo ostvarivanje prava pridonosi učinkovitijem tržišnom iskorištavanju, a potom i zaštiti autorskih i srodnih prava. Takve organizacije pritom djeluju kao spona između nositelja i korisnika takvih prava s korisnim učincima za obje strane.

Rad teži jasno pravno razgraničiti organizaciju za kolektivno ostvarivanje prava od neovisnog upravljačkog subjekta kroz njihovo pojmovno određenje. Izneseno je otežano time što se pojmovi tih dviju organizacija preklapaju u značajnoj mjeri, a i time što su neovisni upravljački subjekti još uvijek novina na području kolektivnog ostvarivanja prava u pravnom, ali i praktičnom smislu. Bez obzira na izneseno, pokazalo se kako su sudionici na tržištu kolektivnog ostvarivanja prava prepoznali gospodarske prednosti koje omogućuje obavljanje kolektivnog ostvarivanja prava preko neovisnog upravljačkog subjekta. Shodno tome, pitanje je vremena kada će se takve organizacije pojaviti i na domaćem tržištu. Pojava neovisnog upravljačkog subjekta na domaćem, ali i ostalim tržištima država članica nameće se kao osjetljiva gospodarsko-socijalna tema jer pojava neovisnog upravljačkog subjekta narušava uspostavljeni monopol organizacije za kolektivno ostvarivanje prava.

Imajući u vidu izostanak odgovarajućih izvora u hrvatskom pravu, u primjeni i tumačenju normi hrvatskog autorskog prava od velike pomoći, naravno uz primjenu odgovarajuće razine opreza i kritičnosti, može biti bogata njemačka pravna književnost koja pruža jednostavan i opsežan pristup predmetnoj pravnoj materiji. Izravna usporedba i povlačenje poveznica moguće je zbog visoke razine identičnosti sadržaja zakonskih rješenja i strukture normi njemačkog i hrvatskog autorskog prava. Tome u prilog govori to što je predmetna materija stvarana pod izravnim utjecajem europske pravne stečevine. Iako u pojedinim slučajevima postoje i određene razlike u izričaju između pojedinih zakonskih odredaba, takve su razlike posljedica konkretnih specifičnosti tih dvaju pravnih sustava koje ne bi trebale utjecati na takvu upotrebu njemačkih pravnih izvora. Korištenje njemačkog prava poželjno je i stoga što pripada krugu pravnih sustava u kojem je domaći zakonodavac našao pravo uzora pri izradi i razvoju domaćeg pravnog sustava. U analizi predmetne materije primjećuje se kako su rješenja njemačkog prava u velikoj mjeri primjenjiva na rješenja hrvatskog autorskog prava, što se posebno odnosi na dijelove njemačkog prava koji je rezultat usklađivanja s europskom pravnom stečevinom koja se primjenjuje i na hrvatsko autorsko pravo.

Strukturno ovaj rad ponajprije pruža kratak uvod u sadržaj autorskih i srodnih prava te njihovo kolektivno ostvarivanje, zatim navodi i obrazlaže uvjete koje osoba mora ostvariti kako bi se kvalificirala kao organizacija za kolektivno ostvarivanje prava, a potom to isto čini i u pogledu neovisnog upravljačkog subjekta. Potom se analiziraju odgovarajuće odredbe nacrta novog prijedloga Zakona o autorskom pravu i srodnim pravima koji je nedavno izašao iz javne rasprave, a na kraju se daje pregled najznačajnijih zaključaka iz prethodnih poglavlja. 


\section{OPĆENITO O AUTORSKIM PRAVIMA I SRODNIM PRAVIMA TE KOLEKTIVNOM OSTVARIVANJU PRAVA}

Kolektivno ostvarivanje prava autora, umjetnika izvođača, filmskih producenata i drugih ovlaštenika rezultat je višestoljetne evolucije na području zaštite autorskih prava. $^{3}$ Autorska prava dijele se na moralna prava (npr. pravo na priznanje autorstva), imovinska prava (npr. pravo distribucije) i druga prava autora (npr. pravo na naknadu za korištenje autorskog djela). Slična podjela postoji i u pogledu srodnih prava umjetnika izvođača, proizvođača fonograma, filmskih producenta itd. Nositelj autorskih prava jest autor odnosno fizička osoba koja stvori autorsko djelo uz koje se vežu autorska prava. ${ }^{4}$ Takva su prava načelno neprenosiva, no to ne znači kako autor ne može ugovorom s drugom osobom osnovati pravo iskorištavanja svog djela ili joj prepustiti ostvarivanje autorskog prava. ${ }^{5}$ Autor time redovito ograničava svoja prava na autorskom djelu. ${ }^{6}$ Tako ugovoreno pravo iskorištavanja može biti isključivo ili neisključivo, a može biti i prostorno ograničeno ili neograničeno. Druge osobe (korisnici) time stječu različite mogućnosti iskorištavanja autorova djela (npr. umnožavanja, stavljanja u promet i izvođenja). ${ }^{7}$ Sukladno načelu slobode uređivanja obveznih odnosa, autor i korisnik stoga slobodno određuju sadržaj i doseg prava iskorištavanja. Takvo se pravo iskorištavanja redovito zasniva ugovorom koji u pravnom prometu nalazimo u različitim oblicima (npr. licenca,

3 Počeci kolektivnog ostvarivanja prava počinju u Francuskoj osnivanjem SACD (1829) i SACEM (1851). Nedugo potom, prve organizacije za kolektivno ostvarivanje prava nastaju u Italiji (SIAE 1882), Njemačkoj (GDT 1903). U Hrvatskoj takvu djelatnost obavlja sedam organizacija od kojih je vjerojatno najpoznatije Hrvatsko društvo skladatelja (HDS). Više o povijesnom razvoju kolektivnog ostvarivanja prava vidi Seifert, F., u: Eichleberger, J., Wirth, T., Seifert, F., Urheberrechtgesetz mit Verwertungsgesselschaftengesetz, Handkommentar, 3. Auflage, Baden-Baden 2020., Einleitung VGG Rbr. 8-16; Gerlach, T., u: Wandtke, A, Bullinger, W., Urheberrecht, UrhG - KUG - VGG -InfoSoc-RL, Praxiskommentar, 5. Auflage, München 2019., Vor $§ 1$ ff. VGG Rbr. 2.

4 Tako vidi Gliha, I., "Raspolaganje autorskim pravom (i srodnim pravima)", Zbornik Hrvatskog društva za autorsko pravo, 5 (2004.), str. 98. Potrebno je, međutim, naglasiti kako je pojam nositelja prava u kontekstu kolektivnog ostvarivanja prava proširen čl. 154. st. 1. t. e) ZAPSP-a i na osobe koje su od izvornog nositelja derivativno stekle pojedina ili sva autorska ili srodna prava (npr. nasljednik ili nakladnik).

5 Više o autorskim pravima vidi čl. 13. do 40. ZAPSP-a. Iznimka u pogledu neprenosivosti autorskih prava postoji u slučaju smrti autora i nasljeđivanja njegovih prava od strane autorovih nasljednika. Tako vidi čl. 41. ZAPSP-a. Sa stajališta usporedivog njemačkog prava vidi Soppe, M., u: Alhberg, H., Götting, H., BeckOK Urheberrecht, 24. Auflage, UrhG \$31 Einräumung von Nutzungsrechten Rbr. 4. S druge strane, više o zasnivanju prava iskorištavanja vidi čl. 44. ZAPSP-a.

6 Tako vidi Gliha, I., "Raspolaganje autorskim pravom (i srodnim pravima)", Zbornik Hrvatskog društva za autorsko pravo, 5 (2004.), str. 99. U tom smjeru također vidi Gliha, I., u: von Lewinski, S., Copyright Throughout the World, Vol. 1, str. 11.57. Tako sa stajališta usporedivog njemačkog prava vidi Schulze, G., u: Dreier, T., Schulze, G., Urheberschutzgesetz, 6. Auflage, 2018., UrhG §31 Einräumung von Nutzungsrechten Rbr. 11.

7 Tako vidi Gliha, I., "Raspolaganje autorskim pravom (i srodnim pravima)", Zbornik Hrvatskog društva za autorsko pravo, 5 (2004.), str. 98. 
Doc. dr. sc. Tomislav Jakšić: Pojam organizacije za kolektivno ostvarivanje prava i neovisnog upravljačkog... Zbornik radova Pravnog fakulteta u Splitu, god. 58, 3/2021, str. 785-814

distribucija, nakladnički ugovor). ${ }^{8}$ Pritom je moguće ugovoriti i pravo korisnika na prijenos svih ili samo nekih prava iskorištavanja trećim osobama. U takvim okolnostima pravo prvog korisnika naziva se pravom kćeri jer takav korisnik stečeno pravo iskorištavanja izvodi izvorno od autora, koji uživa najveća prava u pogledu iskorištavanja svojeg djela. Izvedeno pravo daljnjeg korisnika naziva se pravom unuke jer takvo pravo počiva na pravu kćeri itd. ${ }^{9}$ Bez mogućnosti zasnivanja prava iskorištavanja ili prepuštanja ostvarivanja prava autora nekoj drugoj osobi nije moguće zamisliti ostvarenje gospodarske i društvene svrhe autorskih prava jer bi autorsko djelo tada mogao iskorištavati samo autor. Takvo što ponajprije nije životno niti gospodarski opravdano, a nije niti u interesu autora, a potom ni interesu ostalih izravnih ili neizravnih korisnika autorskog djela (npr. nakladnika književnog djela).

Iz iznesenog proizlazi kako je autor ponajprije ovlašten individualno ostvarivati svoja prava, a potom i omogućiti trećima iskorištavanje svojih djela. ${ }^{10}$ Razumno je pretpostaviti kako je takvo ostvarivanje prava uobičajeno pri zasnivanju početnog prava iskorištavanja novog autorskog djela za koje postoji interes tržišta (npr. između autora i nakladnika koji time stječe pravo iskorištavanja). Međutim, takvo individualno iskorištavanje, zbog svojih prirođenih nedostataka, nije jedini način ostvarivanja prava. To stoga što autoru, primjerice, redovito nije poznato kako treći neovlašteno iskorištavaju njegovo djelo, a redovito nema niti potrebna znanja za odgovarajuće svakodnevno upravljanje pravima i njihovo licenciranje trećima. ${ }^{11}$ Štoviše, kod masovnog iskorištavanja predmeta zaštite (npr. preko interneta) autoru je izrazito teško, čak i nemoguće, nadzirati korištenje te urediti odnos sa svakim pojedinim korisnikom. Takvo uređivanje, kada bi i bilo moguće, iziskivalo bi veliku količinu vremena, a rezultiralo bi i znatnim troškovima što bi se u konačnici negativno odrazilo i na visinu naknade za korištenje autorskog djela. ${ }^{12}$ Izneseno bi

8 U tom smjeru vidi Gliha, I., u: von Lewinski, S., Copyright Throughout the World, Vol. 1, str. 11.57. Tako sa stajališta usporedivog njemačkog prava vidi Soppe, M., u: Alhberg, Götting, BeckOK Urheberrecht, 24. Auflage, UrhG \$31 Einräumung von Nutzungsrechten, §31 Einräumung von Nutzungsrechten Rbr. 5; Schulze, G., u: Dreier, T., Schulze, G., Urheberschutzgesetz, 6. Auflage, 2018., UrhG §31 Einräumung von Nutzungsrechten Rbr. 4. Pritom valja naglasiti kako takvi poslovi koji se nalaze pod nazivom licenca ili distribucija u pravilu ne odgovaraju poslovima koji se u pravnom prometu uobičajeno smatraju takvim poslovima. Na takve ugovore o iskorištavanju primjenjuju se ponajprije trgovački običaji, koji se redovito primjenjuju na takve ugovorne odnose, a tek potom pravila ZAPSP-a o autorskopravnim ugovorima te pravila obveznog prava. U tom smjeru vidi Gliha, I., "Raspolaganje autorskim pravom (i srodnim pravima)", Zbornik Hrvatskog društva za autorsko pravo, 5 (2004.), str. 103. Tako sa stajališta usporedivog njemačkog prava vidi Schulze, G., u: Dreier, T., Schulze, G., Urheberschutzgesetz, 6. Auflage, 2018., UrhG §31 Einräumung von Nutzungsrechten Rbr. 15.

9 Tako sa stajališta usporedivog njemačkog prava vidi Soppe, M., u: Alhberg, Götting, BeckOK Urheberrecht, 24. Auflage, UrhG \$31 Einräumung von Nutzungsrechten, Einführung; Schulze, G., u: Dreier, T., Schulze, G., Urheberschutzgesetz, 6. Auflage, 2018., UrhG §31 Einräumung von Nutzungsrechten Rbr. 15.

10 Tako vidi čl. 155. ZAPSP-a.

11 Tako sa stajališta usporedivog njemačkog prava vidi Freudenberg, C., u: Ahlberg, H., Götting, H., Urheberrecht, UrhG - KUG - VerG - VGG Kommentar, 4. Auflage, München 2018., VGG $\S 1$ Rbr. 1.

12 Tako sa stajališta usporedivog njemačkog prava vidi Seifert, F., u: Eichleberger, J., Wirth, T., Seifert, F., Urheberrechtgesetz mit Verwertungsgesselschaftengesetz, Handkommentar, 3. Auflage, Baden-Baden 2020., Einleitung VGG Rbr. 22. 
Doc. dr. sc. Tomislav Jakšić: Pojam organizacije za kolektivno ostvarivanje prava i neovisnog upravljačkog... Zbornik radova Pravnog fakulteta u Splitu, god. 58, 3/2021, str. 785-814

moglo dovesti do pada interesa za obavljanje bilo kakve kreativne djelatnosti koja rezultira stvaranjem autorskog djela. S druge strane, takav način ostvarivanja prava stvara probleme i korisnicima koji žele steći pravo iskorištavanja autorskih djela većeg broja autora. Takvo individualno ostvarivanje prava znači kako korisnik mora sklopiti ugovore o iskorištavanju autorskog djela sa svakim pojedinim autorom što također nije praktično, a što se u konačnici negativno održava na gospodarsku isplativost i troškove transakcije. ${ }^{13}$ Pored toga, takav način ostvarivanja prava stavlja manje poznate autore u nepovoljan položaj jer će korisnik ograničiti svoje troškove samo na autore za koje postoji interes tržišta, a ako će i ići u pregovore s takvim autorima, kao jača ugovorna strana, moći će im nametnuti nepovoljnije uvjete. ${ }^{14}$

Kako bi se omogućilo učinkovito upravljanje i raspolaganje autorskim pravima, razvijen je model kolektivnog ostvarivanja prava. Pod kolektivnim ostvarivanjem prava podrazumijeva se ostvarivanje autorskih i srodnih prava od strane jedne pravne osobe u interesu i za zajedničku korist više autora. Kolektivno ostvarivanje prava obavljaju ponajprije organizacije za kolektivno ostvarivanje prava. Takve organizacije povezuju nositelje autorskih i srodnih prava te korisnike tih prava. ${ }^{15}$ Organizacija za kolektivno ostvarivanje prava na mjerodavnom tržištu redovito uživa faktični monopol. ${ }^{16}$ Takav monopol često ima i značajnije učinke jer se pojedine nacionalne organizacije kroz dvostrane ugovore povezuju s drugim stranim organizacijama za kolektivno ostvarivanje prava čime se međusobno ovlašćuju na ostvarivanje prava koja zastupaju. Na taj način nacionalna organizacija stječe mogućnost kolektivnog ostvarivanja prava na cjelokupnom svjetskom

13 U tom smjeru sa stajališta usporedivog njemačkog prava vidi Freudenberg, C., u: Ahlberg, H., Götting, H., Urheberrecht, UrhG - KUG - VerG - VGG Kommentar, 4. Auflage, München 2018., VGG $§ 1$ Rbr. 3; Seifert, F., u: Eichleberger, J., Wirth, T., Seifert, F., Urheberrechtgesetz mit Verwertungsgesselschaftengesetz, Handkommentar, 3. Auflage, Baden-Baden 2020., Einleitung VGG Rbr. 23.

14 U tom smjeru vidi Seifert, F., u: Eichleberger, J., Wirth, T., Seifert, F., Urheberrechtgesetz mit Verwertungsgesselschaftengesetz, Handkommentar, 3. Auflage, Baden-Baden 2020., Einleitung VGG Rbr. 4.

15 Tako sa stajališta usporedivog njemačkog prava vidi Heine, R., Holzmüller, T., VGG Verwertungsgesselschaftengesetz, Kommentar, Leck 2019., Einleitung Rbr. 1.

16 Doduše, često se može govoriti i o zakonskom monopolu imajući u vidu, primjerice, čl. 157. st. 4. ZAPSP-a prema kojem Državni zavod za zaštitu intelektualnog vlasništva, kao nadležni regulator na području zaštite autorskih i srodnih prava, može dati odobrenje za obavljanje djelatnosti kolektivnog ostvarivanja prava samo jednoj organizaciji za kolektivno ostvarivanje prava za pojedinu vrstu prava i pojedinu kategoriju nositelja prava, uzevši u obzir broj članova na temelju dobivenih punomoći, broj ugovora o uzajamnom zastupanju s organizacijama za kolektivno ostvarivanje prava u drugim državama kao i druge okolnosti koje upućuju na to da bi ta organizacija za kolektivno ostvarivanje prava najučinkovitije obavljala poslove kolektivnog ostvarivanja prava. Navedeno ne znači kako takav monopol organizacije za kolektivno ostvarivanje prava ima nužno negativan učinak na tržište, štoviše zbog razloga navedenih u prethodnom paragrafu takav je monopol povijesno bio nužan i stoga opravdan. Tako sa stajališta usporedivog njemačkog prava vidi Seifert, F., u: Eichleberger, J., Wirth, T., Seifert, F., Urheberrechtgesetz mit Verwertungsgesselschaftengesetz, Handkommentar, 3. Auflage, Baden-Baden 2020., Einleitung VGG Rbr. 24. 
Doc. dr. sc. Tomislav Jakšić: Pojam organizacije za kolektivno ostvarivanje prava i neovisnog upravljačkog... Zbornik radova Pravnog fakulteta u Splitu, god. 58, 3/2021, str. 785-814

(npr. glazbenom) repertoaru što omogućuje pružanje tzv. one-stop-shop usluge. ${ }^{17}$ Takva koncentracija prava govori u prilog zaključku kako nacionalne organizacije za kolektivno ostvarivanje prava imaju i značajnu tržišnu snagu u odnosu na potencijalne konkurente koji žele pristupiti tom tržištu. Radi sprečavanja eventualne zlouporabe vladajućeg položaja, djelatnost organizacija za kolektivno ostvarivanje prava biva stoga posebno uređena i nadzirana, ponajprije od strane regulatora nadležnog za zaštitu autorskih prava, a potom i regulatora nadležnog za zaštitu tržišnog natjecanja. ${ }^{18}$

Iako se kolektivno ostvarivanje prava kao i autorsko pravo nalazi u domeni nacionalnog prava, europsko pravo ovlašćuje tijela Europske unije da u svom djelovanju uzmu u obzir kulturnu raznolikost te pridonesu procvatu kultura država članica. ${ }^{19} \mathrm{U}$ tom pogledu ne čudi što europski zakonodavac smatra kako organizacije za kolektivno ostvarivanje prava imaju važnu ulogu u promicanju raznolikosti kulturnog izričaja. ${ }^{20}$ Tako je 2005. Europska komisija izdala Preporuku 2005/737/EZ kojom je nastojala snagom svojeg autoriteta, doduše neuspješno, potaknuti države članice na ujednačavanje nekih pravila na području kolektivnog ostvarivanja prava (npr. u pogledu autorove slobode izbora organizacije za kolektivno ostvarivanje prava i obavještavanja autora o cijenama i repertoaru prije započinjanja pregovora s organizacijom). ${ }^{21}$

Europska komisija potom je pribjegla ujednačavanju pravila o kolektivnom ostvarivanju prava kroz Direktivu 2014/26/EU koju su države članice morale implementirati do 10. travnja 2016. Tom se direktivom, osim koordinacije propisa država članica o organizacijama za kolektivno ostvarivanje autorskih i srodnih prava, težilo uspostavi višeg standarda upravljanja, transparentnosti, obavještavanja

17 Tako sa stajališta usporedivog njemačkog prava vidi Freudenberg, C., u: Ahlberg, H., Götting, H., Urheberrecht, UrhG-KUG-VerG-VGG Kommentar, 4. Auflage, München 2018., VGG §1 Rbr. 6; Seifert, F., u: Eichleberger, J., Wirth, T., Seifert, F., Urheberrechtgesetz mit Verwertungsgesselschaftengesetz, Handkommentar, 3. Auflage, Baden-Baden 2020., Einleitung VGG Rbr. 63-64; Gerlach, T., u: Wandtke, A, Bullinger, W., Urheberrecht, UrhG - KUG - VGG - InfoSoc-RL, Praxiskommentar, 5. Auflage, München 2019., Vor $\S \S 1$ ff. VGG Rbr. 21. Više o tom sporazumu koji domaći zakonodavac određuje kao "sporazum o zastupanju" vidi čl. 154. st. 1. t. 1. ZAPSP-a.

18 Tako, primjerice, organizacija za kolektivno ostvarivanje prava mora dobiti odobrenje Državnog zavoda za intelektualno vlasništvo (čl. 157. st. 1. ZAPSP-a) nakon čega je djelatnost organizacije i dalje podložna nadzoru regulatora (čl. 170. ZAPSP-a). Tako vidi Seifert, F., u: Eichleberger, J., Wirth, T., Seifert, F., Urheberrechtgesetz mit Verwertungsgesselschaftengesetz, Handkommentar, 3. Auflage, Baden-Baden 2020., Einleitung VGG Rbr. 25.

19 Tako vidi čl. 167. Ugovora o funkcioniranju Europske unije, SL C 202, 7.6.2016., str. 1-388.

20 Tako vidi t. 3. preambule Direktiva 2014/26/EU od 25. veljače 2014. o kolektivnom ostvarivanju autorskog prava i srodnih prava te izdavanju odobrenja za više državnih područja za prava na internetsko korištenje glazbenih djela na unutarnjem tržištu (dalje: Direktiva 2014/26/EU), SL L 84, 20. III. 2014., str. 72-98.

${ }^{21}$ Preporuka Komisije 2005/737/EZ od 18. svibnja 2005. o kolektivnom prekograničnom upravljanju autorskim i srodnim pravima za zakonite internetske glazbene usluge, SL L 276, 21. X. 2005., str. 54-57. Pritom je potrebno naglasiti kako je preporuka zapravo izdana 18. studenog 2005. Tako vidi ispravak predmetne preporuke objavljen u SL L 284, 27. X. 2005., str. 10. Vezano za načelnu neuspješnost predmetnih preporuka vidi t. 6. preambule Direktive 2014/26/EU. Također vidi Freudenberg, C., u: Ahlberg, H., Götting, H., Urheberrecht, UrhG - KUG - VerG - VGG Kommentar, 4. Auflage, München 2018., VGG §1 Rbr. 18-20. 
i odgovornosti takvih organizacija prema nositeljima prava koja zastupaju, ali i korisnicima takvih prava. Pored toga, direktivom se nastoje posebno urediti i pravila o kolektivnom ostvarivanju internetskih prava na glazbena djela na području više država članica. Radi se o instrumentu koji počiva na načelu minimalne harmonizacije što znači kako se njome utvrđuju minimalni pravni standardi ispod kojih država članica ne može ići. ${ }^{22}$ Domaći zakonodavac uskladio je hrvatski pravni sustav s odredbama Direktive 2014/26/EU kroz izmjene i dopune ZAPSP-a iz 2017. godine. ${ }^{23}$ Tim izmjenama i dopuna ZAPSP-a, osim što je pojam organizacije za kolektivno ostvarivanje prava usklađen sa zahtjevima Direktive 2014/26/EU, u hrvatsko autorsko pravo uvedena je i nova pravna osoba za kolektivno ostvarivanje prava, tzv. neovisni upravljački subjekt. Time je direktiva nametnula državama članicama uspostavu dvojakog načina kolektivnog ostvarivanja prava, konkretno kroz "organizaciju za kolektivno ostvarivanje prava" (vidi čl. 3. st. 1. t. a) Direktive 2014/26/EU te kroz "neovisni upravljački subjekt" (vidi čl. 3. st. 1. t. b) Direktive 2014/26/EU. Pritom neovisni upravljački subjekt podliježe nižoj razini nadzora od organizacije za kolektivno ostvarivanje prava. ${ }^{24}$

Pojam organizacije za kolektivno ostvarivanje prava određen je čl. 154. st. 1. t. b) ZAPSP-a dok je pojam neovisnog upravljačkog subjekta određen čl. 154. st. 1. t. d) ZAPSP-a. Iz tih zakonskih odredaba očito je kako organizacija za kolektivno ostvarivanje prava dijeli brojne sličnosti s neovisnim upravljačkim subjektom, međutim, dijeli i par ključnih razlika. U svakom slučaju, neovisno o tome o kojoj se od tih dviju organizacija radi, svaka osoba koja želi obavljati djelatnost kolektivnog ostvarivanja prava mora ispuniti određene zakonom propisane opće i posebne uvjete. ${ }^{25}$

\section{POJAM ORGANIZACIJE ZA KOLEKTIVNO OSTVARIVANJE PRAVA}

Prema čl. 3. st. 1. t. a) Direktive 2014/26/EU, "organizacija za kolektivno ostvarivanje prava" znači svaka organizacija koja je u skladu sa zakonom ili prijenosom prava, odobrenjem ili drugim ugovornim sporazumom ovlaštena za upravljanje autorskim ili srodnim pravima u ime više od jednog nositelja prava u

22 Tako vidi t. 9. preambule Direktive 2014/26/EU. Tako također vidi Freudenberg, C., u: Ahlberg, H., Götting, H., Urheberrecht, UrhG - KUG - VerG - VGG Kommentar, 4. Auflage, München 2018., VGG §1 Rbr. 24; Seifert, F., u: Eichleberger, J., Wirth, T., Seifert, F., Urheberrechtgesetz, mit Verwertungsgesselschaftengesetz, Handkommentar, 3. Auflage, Baden-Baden 2020., Einleitung VGG Rbr. 95; Heine, R., Holzmüller, T., VGG Verwertungsgesselschaftengesetz Kommentar, Leck 2019. Einleitung Rbr. 28.

23 Zakon o izmjenama i dopunama Zakona o autorskim i srodnim pravima, Narodne novine br. 62/17.

24 Tako sa stajališta usporedivog njemačkog prava vidi Heine, R., Holzmüller, T., VGG Verwertungsgesselschaftengesetz. Kommentar, Leck 2019., §4 Rbr. 1.

25 Opći uvjeti jednako se primjenjuju na organizaciju za kolektivno ostvarivanje prava i neovisnog upravljačkog subjekta, dok se na svaku od tih dviju organizacija primjenjuju i dva posebna uvjeta različitog sadržaja za svaku od organizacija. 
zajedničku korist tih nositelja prava kao svojom jedinom ili glavnom svrhom i koja ispunjava jedan ili oba sljedeća kriterija: i. u vlasništvu je svojih članova ili pod njihovim nadzorom; ii. ustrojena je na neprofitnoj osnovi. Po uzoru na predmetnu odredbu direktive čl. 154. st. 1. t. b) ZAPSP-a određuje kako je "organizacija za kolektivno ostvarivanje prava" ona organizacija koja je na temelju zakona, punomoći ili ugovora ovlaštena ostvarivati autorska ili srodna prava za dva ili više nositelja prava neovisno o tome djeluje li u svoje ime ili u ime nositelja prava, za njihovu zajedničku korist, kojoj je to jedina ili glavna svrha i koja: pripada ili je pod kontrolom svojih članova i koja je ustrojena na neprofitnoj osnovi.

Direktiva 2014/26/EU i ZAPSP time određuju minimalne zahtjeve koji moraju biti ispunjeni kako bi se neka osoba mogla kvalificirati kao organizacija za kolektivno ostvarivanje prava. Takvi zahtjevi mogu se podijeli na četiri opća kumulativna i dva posebna alternativna uvjeta. Kumulativni uvjeti su: 1) ostvarivanje autorskih i srodnih prava, 2) kolektivno ostvarivanje prava za više nositelja prava, 3) ostvarivanje prava za zajedničku korist (račun) nositelja prava te 4) kolektivno ostvarivanje autorskih i srodnih prava kao jedina ili glavna svrha organizacije. Iako Direktiva 2014/26/EU u pogledu dva preostala posebna uvjeta izričito određuje alternativitet, ZAPSP takve uvjete određuje kumulativno. Tako direktiva određuje kako je organizacija za kolektivno ostvarivanje prava ona "koja ispunjava jedan ili oba sljedeća kriterija": 1) u vlasništvu je svojih članova ili pod njihovim nadzorom te 2) ustrojena je na neprofitnoj osnovi. S druge strane, ZAPSP određuje kako je organizacija za kolektivno ostvarivanje prava ona "i koja" 1) pripada ili je pod kontrolom svojih članova i 2) ustrojena je na neprofitnoj osnovi. Nije poznato zašto je domaći zakonodavac na taj način drugačije prenio odredbu čl. 3. st. 1. t. a) Direktive 2014/26/EU u ZAPSP jer za takvo strože uređenje od uređenja koje predviđa direktiva nema opravdanog razloga. ${ }^{26}$

Zahtjev ostvarivanja autorskih i srodnih prava podrazumijeva prava koja štiti ZAPSP (npr. moralna, imovinska i druga prava autora, umjetnika izvođača, proizvođača fonograma, filmskih producenata itd.). ${ }^{27}$ Dok Direktiva 2014/26/EU govori o ostvarivanju prava na temelju zakona, prijenosa prava, odobrenja ili drugog ugovornog sporazuma, ZAPSP gotovo pa identično govori o ostvarivanju prava na temelju zakona, punomoći ili ugovora. Takvo ostvarivanje prava, primjerice, počiva na ugovoru koji organizacija za kolektivno ostvarivanje prava sklapa $\mathrm{s}$ nositeljem prava (npr. ugovoru o ostvarivanju prava), zatim na temelju ugovora o uzajamnom zastupanju s drugom organizacijom za kolektivno ostvarivanje prava ili nekom sličnom ugovoru (npr. ugovoru o licenci ili ustupanju prava iskorištavanja). ${ }^{28}$

26 Više o tome vidi kasnije u ovom poglavlju.

27 Više o vrstama autorskih prava vidi ranije pod "2. Općenito o autorskim pravima i srodnim pravima te kolektivnom ostvarivanju prava". Tako sa stajališta usporedivog njemačkog prava vidi Freudenberg, C., u: Ahlberg, H., Götting, H., Urheberrecht, UrhG - KUG - VerG - VGG Kommentar, 4. Auflage, München 2018., VGG §2 Rbr. 4.

28 Tako sa stajališta usporedivog njemačkog prava vidi Heine, R., Holzmüller, T., VGG Verwertungsgesselschaftengesetz. Kommentar, Leck 2019., \$2 Rbr. 16. U tom smjeru sa stajališta njemačkog prava vidi Kling, C., Gebietsübergreifende Vergabe von Online-Rechten an Musikwerken, Problemme einer effizienten Lizenzeirungspraxis unter Geltung des VGG, Leck 2018., str. 134. 
Doc. dr. sc. Tomislav Jakšić: Pojam organizacije za kolektivno ostvarivanje prava i neovisnog upravljačkog... Zbornik radova Pravnog fakulteta u Splitu, god. 58, 3/2021, str. 785-814

Odredba čl. 156. st. 2. ZAPSP-a tako navodi kako kolektivno ostvarivanje prava može obuhvatiti osobito: prava autora (npr. pravo reproduciranja glazbenih djela, distribucije, pravo na naknadu za javnu posudbu), prava umjetnika izvođača (npr. pravo javnog priopćavanja i prikazivanja izvedbe), prava proizvođača fonograma (npr. pravo stavljanja na raspolaganje javnosti), prava filmskih producenata (npr. pravo na naknadu za javu posudbu) i prava nakladnika (npr. pravo na naknadu za reproduciranje pisanih izdanja). Navedeni popis prava nije taksativan, već samo egzemplaran što znači kako kolektivno ostvarivanje prava može obuhvatiti i druga prava koja nisu navedena u toj zakonskoj odredbi. Predmet kolektivnog ostvarivanja mogu biti autorska i srodna prava koja počivaju na stranom pravu (npr. na njemačkom Zakonu o autorskim i srodnim pravima - Urhebergesetz). ${ }^{29}$ Kolektivno ostvarivanje prava pritom obuhvaća i prava koja su izvedena iz autorskih i srodnih prava kao što je, primjerice, pravo zahtijevati prestanak radnje koja vrijeđa pravo nositelja te propuštanje takvih ili sličnih radnji ubuduće, zatim popravljanje nanesene štete koja je nastala takvom povredom prava nositelja, plaćanje naknade za neovlašteno korištenje itd. ${ }^{30}$ Iz toga je vidljivo kako je zakonodavac vrlo široko odredio sadržaja prava koja mogu biti predmetom kolektivnog ostvarivanja prava. Drugim riječima, nositelju prava prepušten je izbor hoće li individualno ostvarivati pojedina prava koju mu pripadaju ili će prepustiti da se takva prava ostvaruju kolektivno. ${ }^{31}$ Zakon izričito određuje u čl. 156. st. 3. ZAPSP-a koja se prava mogu ostvarivati samo preko organizacije za kolektivno ostvarivanje prava jer u navedenim slučajevima individualno ostvarivanje prava nije moguće ili je ono moguće sam u ograničenoj mjeri. $^{32}$

Pored navedenog, organizacija za kolektivno ostvarivanje prava mora ostvarivati autorska ili srodna prava za dva ili više nositelja prava za njihovu zajedničku korist. Radi se o kvalifikaciji kolektivnog ostvarivanja prava za više nositelja prava. Nositelj prava jest svaka osoba ili subjekt koji je nositelj autorskog ili srodnog prava, ili koji je na temelju ugovora o iskorištavanju prava ili zakona ovlašten

29 U tom smjeru sa stajališta usporedivog njemačkog prava vidi Heine, R., Holzmüller, T., VGG Verwertungsgesselschaftengesetz Kommentar, Leck 2019., §2 Rbr. 10.

30 Tako vidi čl. 174. ZAPSP-a. U tom smjeru sa stajališta usporedivog njemačkog prava vidi Freudenberg, C., u: Ahlberg, H., Götting, H., Urheberrecht, UrhG - KUG - VerG - VGG Kommentar, 4. Auflage, München 2018., VGG §2 Rbr. 10.

31 Tako sa stajališta usporedivog njemačkog prava vidi Freudenberg, C., u: Ahlberg, H., Götting, H., Urheberrecht, UrhG - KUG - VerG - VGG Kommentar, 4. Auflage, München 2018., VGG §2 Rbr. 7.

32 Tako je samo preko organizacije za kolektivno ostvarivanje prava moguće ostvarivati pravo radiodifuzijskog emitiranja i reemitiranja, pravo na naknadu za radiodifuzijsko emitiranje, određena prava iznajmljivanja autorskog djela ili izvedbe umjetnika izvođača kada se radi o snimljenim glazbenim djelima i glazbenim izvedbama, pravo na naknadu za javnu posudbu itd. U tom smjeru sa stajališta usporedivog njemačkog prava vidi Freudenberg, C., u: Ahlberg, H., Götting, H., Urheberrecht, UrhG - KUG - VerG - VGG Kommentar, 4. Auflage, München 2018., VGG §2 Rbr. 8. U nekim državama članicama, ovlasti kolektivnog ostvarivanja prava počivaju i u široj mjeri na zakonskoj ovlasti nego što je to prema njemačkom i hrvatskom pravu (npr. u Francuskoj i Nizozemskoj). Tako vidi Gerlach, T., u: Wandtke, A, Bullinger, W., Urheberrecht, UrhG - KUG - VGG - InfoSoc-RL, Praxiskommentar, 5. Auflage, München 2019., Vor $\S 1$ ff. VGG Rbr. 26. 
Doc. dr. sc. Tomislav Jakšić: Pojam organizacije za kolektivno ostvarivanje prava i neovisnog upravljačkog... Zbornik radova Pravnog fakulteta u Splitu, god. 58, 3/2021, str. 785-814

ubirati dio prihoda od prava. ${ }^{33}$ To može biti tvorac djela ili izvedbe (npr. autor ili umjetnik izvođač), osobe koje imaju pravo ubirati dio prihoda na temelju zakona (npr. nasljednici autora) ili na temelju ugovora o iskorištavanju autorskog prava (npr. nakladnik ili filmski producent). ${ }^{34}$ Nositelj prava, međutim, mora biti osoba različita od organizacije za kolektivno ostvarivanje prava. Prema tome, osoba koja ostvaruje takva prava za jednog nositelja prava, čak i kada ostvaruje prava u pogledu više djela, ne smatra se organizacijom za kolektivno ostvarivanje prava. ${ }^{35}$ Izneseno potvrđuje i korištenje izraza "kolektivno" u nazivu organizacije pri čemu kolektiv upućuje na ostvarivanje prava za više nositelja. To mogu biti, primjerice, menadžeri i agenti koji takva prava ostvaruju samo za jednog nositelja prava. ${ }^{36}$ Pored toga, menadžeri i agenti nositelja prava koji djeluju kao posrednici i zastupaju nositelje prava u njihovim odnosima s organizacijama za kolektivno ostvarivanje prava ne smatraju se organizacijom za kolektivno ostvarivanje prava jer ne ostvaruju prava na način da određuju cijene, izdaju odobrenja za korištenje ili naplaćuju naknadu za korištenje tih prava. ${ }^{37}$ Takvo određivanje cijene, izdavanje odobrenja i naplata naknade karakteristično je za organizaciju za kolektivno ostvarivanje prava koja takva prava ostvaruje u pogledu cjelokupnog repertoara koji zastupa. ${ }^{38}$ Organizacija za kolektivno ostvarivanje prava tada naplaćuje naknadu na paušalnoj osnovi (ovisno o kategoriji korisnika prava) za zajedničku korist svih nositelja određene

33 Tako vidi čl. 154. st. 1. t. e) ZAPSP-a. Sa stajališta usporedivog njemačkog prava vidi $\S 5$. st. 1. Gesetz über die Wahrnehmung von Urheberrechten und verwandten Schutzrechten durch Verwertungsgesellschaften (dalje: VGG).

34 Tako su članovi GEMA-e, kao njemačke organizacije za kolektivno ostvarivanje prava, pored kompozitora i tekstopisaca, također i glazbeni nakladnici. Tako sa stajališta usporedivog njemačkog prava vidi Freudenberg, C., u: Ahlberg, H., Götting, H., Urheberrecht, UrhG - KUG - VerG $V G G$ Kommentar, 4. Auflage, München 2018., VGG \$2 Rbr. 15; Heine, R., Holzmüller, T., VGG Verwertungsgesselschaftengesetz Kommentar, Leck 2019., §2 Rbr. 12.

35 Tako sa stajališta usporedivog njemačkog prava vidi Schulze, G., u: Dreier, T., Schulze, G., Urheberschutzgesetz, 6. Auflage, 2018., VGG §2 Verwertungsgesellschaft Rbr. 7; Freudenberg, C., u: Alhberg, H., Götting, H., BeckOK Urheberrecht, 24. Auflage, VGG §2 Verwertungsgesselschaft Rbr. 13; Heine, R., Holzmüller, T., VGG Verwertungsgesselschaftengesetz Kommentar, Leck 2019., §2 Rbr. 17. Iznimke u tom pogledu mogu postojati kada se radi o osobama koje su povezane putem članstva, npr. kada je organizacija za kolektivno ostvarivanje prava društvo majka u drugoj pravnoj osobi koja potom temeljem ovlaštenja društva majke formalno ostvaruje kolektivna prava samo za majku, a čime zapravo neizravno ostvaruje kolektivna prava za više nositelja prava (npr. GEMA i PRS osnovali su CELAS $\mathrm{GmbH}$ ). Više o tome vidi Schulze, G., u: Dreier, T., Schulze, G., Urheberschutzgesetz, 6. Auflage, 2018., VGG §2 Verwertungsgesellschaft Rbr. 7. Za suprotno stajalište prema kojem bit predmetnog zahtjeva ne počiva na broju nositelja prava, već na mnoštvu autorskih i srodnih prava koja se kolektivno ostvaruju, vidi Kling, C., Gebietsübergreifende Vergabe von Online-Rechten an Musikwerken, Problemme einer effizienten Lizenzeirungspraxis unter Geltung des VGG, Leck 2018., str. 137.

36 U tom smjeru sa stajališta usporedivog njemačkog prava vidi Freudenberg, C., u: Ahlberg, H., Götting, H., Urheberrecht, Urh $G-K U G-\operatorname{Ver} G-V G G$ Kommentar, 4. Auflage, München 2018., VGG $\$ 2$ Rbr. 13.

37 U tom smjeru vidi t. 16. preambule Direktive 2014/26/EU. Iako predmetna točka preambule navedeno konstatira u kontekstu neovisnog upravljačkog subjekta, navedeno je jednako primjenjivo i na organizaciju za kolektivno ostvarivanje prava. Tako sa stajališta usporedivog njemačkog prava vidi Freudenberg, C., u: Ahlberg, H., Götting, H., Urheberrecht, UrhG - KUG - VerG - VGG Kommentar, 4. Auflage, München 2018., VGG §2 Rbr. 13.

38 Prema čl. 154. st. 1. t. n) repertoarom se smatra skup autorskih djela ili predmeta srodnih prava za koje organizacija za kolektivno ostvarivanje prava ostvaruje prava. 
Doc. dr. sc. Tomislav Jakšić: Pojam organizacije za kolektivno ostvarivanje prava i neovisnog upravljačkog... Zbornik radova Pravnog fakulteta u Splitu, god. 58, 3/2021, str. 785-814

vrste autorskih prava (npr. određivanjem jedinstvene naknade za korištenje glazbenog djela čija visina ne ovisi o kvaliteti ili popularnosti pojedinog glazbenog djela) koju potom raspodjeljuje nositeljima prava ${ }^{39} \mathrm{~S}$ druge strane, naknada koju za ostvarivanje prava utvrđuje pojedini menadžer i agent ovisi o pojedinačnoj kvaliteti i tržišnoj vrijednosti određenog djela zastupanog nositelja. ${ }^{40}$ Tada nema potrebe za raspodjelom naplaćenih naknada nositeljima prava jer je nositelj prava samo jedna osoba koju takav menadžer i agent zastupa te kojoj pripada tako ostvareni prihod.

Takvo ostvarivanje prava organizacija za kolektivno ostvarivanje prava poduzima u svoje ime ili u ime nositelja prava, ali za njihovu zajedničku korist. Korišteni izraz "za njihovu zajedničku korist" ponajprije upućuje na zaključak kako se odnos između organizacije za kolektivno ostvarivanje prava i nositelja prava kvalificira kao "odnos povjerenja". Kod odnosa povjerenja (njem. treuhänderische Wahrnehmung der Rechte) prava koja organizacija za kolektivno ostvarivanje prava ostvaruje ne pripadaju toj organizaciji već drugim osobama koje organizacija kao povjerenik zastupa (nositeljima prava). ${ }^{41}$ Izraz ostvarivanje prava "za zajedničku korist" nositelja prava također upućuje na zaključak kako se takvo ostvarivanje ostvaruje za račun nositelja prava. Takvo što potvrđuje engleski i francuski prijevod čl. 3. st. 1. t. a) Direktive 2014/26/EU. Tako engleska verzija koristi izraz "on behalf of", a francuska "pour le compte" što u prijevodu na hrvatski jezik odgovara izričaju "za račun". Štoviše, takav zaključak izričito potvrđuje čl. 157. st. 3. ZAPSP-a određujući

39 Takav način kolektivnog ostvarivanja prava poznaje iznimke koje ovise o svojstvima pojedinih autorskih djela, npr. u nakladništvu takva se naknada neće primjenjivati na komercijalno isplativije primarno pravo javne objave nekog književnog djela, već tek na sekundarna (naknadna) prava na objavu tog književnog djela. Tako i općenito sa stajališta usporedivog njemačkog prava vidi Schulze, G., u: Dreier, T., Schulze, G., Urheberschutzgesetz, 6. Auflage, 2018., VGG §2 Verwertungsgesellschaft Rbr. 8; Freudenberg, C., u: Alhberg, H., Götting, H., BeckOK Urheberrecht, 24. Auflage, VGG \$2 Verwertungsgesselschaft Rbr. 14. Takav se način kolektivnog ostvarivanja prava ne primjenjuje na neovisni upravljački subjekt koji prema korisnicima može primijeniti tržišne cijene (npr. koja ovisi o kvaliteti ili popularnosti autorskog djela). Tako vidi Schulze, G., u: Dreier, T., Schulze, G., Urheberschutzgesetz, 6. Auflage, 2018., VGG §4 Verwertungsgesellschaft Rbr. 2.

40 Tako sa stajališta usporedivog njemačkog prava vidi Freudenberg, C., u: Ahlberg, H., Götting, H., Urheberrecht, UrhG - KUG - VerG - VGG Kommentar, 4. Auflage, München 2018., VGG §2 Rbr. 14.

${ }_{41}$ Takav se odnos ponajprije temelji na unutarnjem odnosu između organizacije (povjerenika) $\mathrm{i}$ nositelja prava koji počiva na ugovoru ili zakonu koji ovlašćuje povjerenika da ostvaruje prava koja pripadaju njegovu nositelju, za njegov račun. Nakon toga u vanjskom odnosu povjerenik djeluje prema trećima u svoje ime ili u ime nositelja prava čija je prava ovlašten ostvarivati, ali uvijek za njihov račun. U predmetnom odnosu prava koja ostvaruje organizacija ne pripadaju organizaciji već nositeljima prava koji joj povjeravaju ostvarivanje svojih prava kao povjereniku. Temeljem takvog odnosa povjerenja organizacija za kolektivno ostvarivanje prava u vanjskom odnosu s trećima povjerena prava ostvaruje štiteći interese osoba koje su joj povjerile ostvarivanje tih prava. Pritom pojedini nositelji prava nemaju izravna prava prema trećoj osobi (korisniku) s naslova ugovora koji je organizacija, kao povjerenik, sklopila s korisnikom za račun nositelja prava, ali u svoje ime. Ako to čini u njihovo ime, takva prava prema trećem s naslova tako sklopljenog ugovora mogao bi ostvariti izravno i nositelj prava. U ostvarivanju prava nositelja s trećima povjerenik se mora pridržavati ugovorenih i zakonom određenih uvjeta. Stoga ne čudi što takvo kolektivno ostvarivanje prava nadzire i kontrolira nadležnoi regulator. Tako sa stajališta usporedivog njemačkog prava vidi Freudenberg, C., u: Ahlberg, H., Götting, H., Urheberrecht, UrhG $K U G-V e r G-V G G$ Kommentar, 4. Auflage, München 2018., VGG §2 Rbr. 17; Schulze, G., u: Dreier, T., Schulze, G., Urheberschutzgesetz, 6. Auflage, 2018., VGG §2 Verwertungsgesellschaft Rbr. 4-5; Kling, C., Gebietsübergreifende Vergabe von Online-Rechten an Musikwerken, Problemme einer effizienten Lizenzeirungspraxis unter Geltung des VGG, Leck 2018., str. 137; Heine, R., Holzmüller, T., VGG Verwertungsgesselschaftengesetz, Kommentar, Leck 2019., §2 Rbr. 19. 
Doc. dr. sc. Tomislav Jakšić: Pojam organizacije za kolektivno ostvarivanje prava i neovisnog upravljačkog... Zbornik radova Pravnog fakulteta u Splitu, god. 58, 3/2021, str. 785-814

kako organizacija za kolektivno ostvarivanje prava ostvaruje prava u svoje ime ili u ime nositelja prava, a "za račun nositelja prava". ${ }^{42}$ Tome u prilog govori i čl. 154. st. 1. t. j) ZAPSP-a prema kojem se prihod od prava podrazumijeva prihodom koji organizacija za kolektivno ostvarivanje prava ostvari "za račun nositelja prava". Iz prethodnog iznesenog stoga proizlazi kako nije od utjecaja ostvaruje li organizacija, kao povjerenik, autorska i srodna prava u svoje ime ili u ime nositelja tih prava, već samo da se takva prava ostvaruju za račun nositelja prava koje organizacija zastupa.$^{43}$ Drugim riječima, organizacija ne može kolektivno ostvarivati autorska i srodna prava za vlastiti račun. Pravni pojam "za tuđi račun" poznaje obvezno pravo, a od posebnog je značaja u trgovačkom pravu. ${ }^{44}$ Djelovanje za račun nositelja prava znači kako svi gospodarski učinci ugovora koje organizacija za kolektivno ostvarivanje sklapa s trećima, kao korisnicima prava, pripadaju nositeljima prava. ${ }^{45}$ Nakladnici, menadžeri i agenti koji autorska i srodna prava ostvaruju za svoj račun, ostvarujući pritom dobit, ne mogu se stoga kvalificirati kao organizacije za kolektivno ostvarivanje prava. ${ }^{46} \mathrm{Ne}$ postoji li između onoga tko ostvaruje autorska i srodna prava, $s$ jedne strane, te nositelja tih prava, s druge strane, predmetni odnos povjerenja, nadležni regulator ne može provoditi nadzor nad takvim ostvarivanjem prava jer se takva osoba ne smatra organizacijom za kolektivno ostvarivanje prava. ${ }^{47}$ Drugim riječima, osobe koje se ne mogu kvalificirati kao organizacije za kolektivno

42 Tako vidi čl. 157. st. 3. ZAPSP-a.

43 Prema usporedivom njemačkom pravu također nema dvojbe kako se takva prava ostvaruju za račun nositelja prava. Tako odredba $\$ 2$ VGG definirajući organizaciju za kolektivno ostvarivanje prava izričito određuje kako organizacija kolektivno ostvaruje prava za račun (njem. für Rechnung) više nositelja prava. Više o tome vidi Heine, R., Holzmüller, T., VGG Verwertungsgesselschaftengesetz, Kommentar, Leck 2019., §2 Rbr. 18.

${ }_{44}$ Tako se, primjerice, komisionar obvezuje obaviti za proviziju poslove u svoje ime, ali za račun komitenta (čl. 785. st. 1. Zakona o obveznim odnosima (dalje: ZOO), Narodne novine br. 35/05, 41/08, 125/11, 78/15, 29/18), dok se otpremnik (špediter) obvezuje u svoje ime, a za račun nalogodavca organizirati prijevoz robe, dakle sklopiti potrebne ugovore s prijevoznicima i obaviti potrebne i ugovorne radnje za izvršenje prijevoza (čl. 849. st. 1. ZOO-a). Dok su komisija i špedicija u pravilu jednokratne i kratkotrajnog karaktera, kolektivno ostvarivanje prava trajne je naravi što je u značajnoj mjeri posljedica povjereničke naravi takvog ostvarivanja prava.

45 Tako sa stajališta usporedivog njemačkog prava vidi Freudenberg, C., u: Ahlberg, H., Götting, H., Urheberrecht, UrhG - KUG - VerG - VGG Kommentar, 4. Auflage, München 2018., VGG §2 Rbr. 19; Heine, R., Holzmüller, T., VGG Verwertungsgesselschaftengesetz Kommentar, Leck 2019., §2 Rbr. 19. Tome u prilog govori i zakonski pojam organizacije za kolektivno ostvarivanje prava prema kojoj takva organizacija pripada ili je pod kontrolom svojih članova te je ustrojena na neprofitnoj osnovi. Više o tim zakonskim zahtjevima u nastavku teksta.

46 Tako t. 16. preambule Direktive 2014/26/EU navodi kako se producenti, organizacije za radiofuziju, nakladnici koji ostvaruju vlastita prava kao i prava drugih nositelja prava prenesena pojedinačnim sporazumima koji djeluju u vlastitom interesu, a zatim i menadžeri i agenti nositelja prava koji djeluju kao posrednici i zastupaju nositelje prava u njihovim odnosima s organizacijama za kolektivno ostvarivanje prava - ne smatraju neovisnim upravljačkim subjektima. Iako čl. 154. st. 1. t. d) ZAPSP-a predmetno navodi samo u pogledu neovisnog upravljačkog subjekta, izneseno se jednako primjenjuje i na organizacije za kolektivno ostvarivanje prava. Tako sa stajališta usporedivog njemačkog prava vidi Heine, R., Holzmüller, T., VGG Verwertungsgesselschaftengesetz, Kommentar, Leck 2019., §2 Rbr. 19.

Tako sa stajališta usporedivog njemačkog prava vidi Freudenberg, C., u: Ahlberg, H., Götting, H., Urheberrecht, UrhG - KUG - VerG - VGG Kommentar, 4. Auflage, München 2018., VGG §2 Rbr. 20.

47 Tako sa stajališta usporedivog njemačkog prava vidi Freudenberg, C., u: Ahlberg, H., Götting, H., Urheberrecht, UrhG-KUG-VerG-VGG Kommentar, 4. Auflage, München 2018., VGG §2 Rbr. 20. 
Doc. dr. sc. Tomislav Jakšić: Pojam organizacije za kolektivno ostvarivanje prava i neovisnog upravljačkog... Zbornik radova Pravnog fakulteta u Splitu, god. 58, 3/2021, str. 785-814

ostvarivanje prava ne potpadaju pod nadzor nadležnog regulatora (Državnog zavoda za intelektualno vlasništvo, dalje: DZIV) koji se primjenjuje na takve organizacije.

Pored toga, domaći zakonodavac pritom se odlučio za korištenje izraza "za zajedničku korist nositelja prava" u definiciji organizacije za kolektivno ostvarivanje prava, dok u odredbi kasnije izričito navodi kako se takva prava ostvaruju za račun nositelja prava. Stoga bi bilo prikladnije izmijeniti definiciju iz čl. 154. st. 1. t. b) ZAPSP-a na način da se uz izraz "za zajedničku korist" nositelja prava u zakonsku definiciju doda i izraz "za račun više nositelja prava" te da se potom izbriše kao nepotrebna odredba čl. 157. st. 3. ZAPSP-a koja značajnim dijelom ponavlja sadržaj prethodno navedene odredbe čl. 154. ZAPSP-a.

Uz to, kolektivno ostvarivanje prava mora predstavljati jedinu ili glavnu svrhu organizacije za kolektivno ostvarivanje prava. ${ }^{48}$ Kolektivno ostvarivanje prava mora biti u fokusu poslovnih aktivnosti organizacije za kolektivno ostvarivanje prava. Povremeno ili kratkotrajno obavljanje kolektivnog ostvarivanja prava stoga ne udovoljava predmetnom zahtjevu. ${ }^{49}$ To ne znači kako organizacija za kolektivno ostvarivanje prava ne može obavljati i druge djelatnosti kao sporedne djelatnosti. Obavljanje takvih djelatnosti, međutim, ne smije biti smetnja kvalitetnom obavljanju glavne svrhe organizacije tj. djelatnosti kolektivnog ostvarivanja autorskih i srodnih prava. Je li kolektivno ostvarivanje prava jedina ili glavna svrha organizacije činjenično je pitanje (npr. ovisi o broju zaposlenih koji obavljaju takve poslove, vrijednosti uložene imovine u obavljanje takve djelatnosti kao i vrijednost ostvarenih prihoda od takve djelatnosti). Stoga se takva ocjena ne može svesti samo na utvrđivanje sadržaja predmeta poslovanja kao evidencijskog podatka u sudskom registru. ${ }^{50}$ Dio njemačke pravne književnosti, međutim, smatra kako prag razgraničenja između glavne i sporedne djelatnosti kolektivnog ostvarivanja prava ne treba odrediti prestrogo s ciljem sprečavanja izbjegavanja primjene pravila koja se odnose na organizacije za kolektivno ostvarivanje prava. ${ }^{51}$

Uz navedene uvjete, zakonodavac određuje i dva dodatna posebna uvjeta za kvalifikaciju neke osobe kao organizacije za kolektivno ostvarivanje prava. To je 1)

48 Tako sa stajališta usporedivog njemačkog prava vidi Schulze, G., u: Dreier, T., Schulze, G., Urheberschutzgesetz, 6. Auflage, 2018., VGG §2 Verwertungsgesellschaft Rbr. 14; Kling, C., Gebietsübergreifende Vergabe von Online-Rechten an Musikwerken, Problemme einer effizienten Lizenzeirungspraxis unter Geltung des VGG, Leck 2018., str. 135.

49 Tako sa stajališta usporedivog njemačkog prava vidi Kling, C., Gebietsübergreifende Vergabe von Online-Rechten an Musikwerken, Problemme einer effizienten Lizenzeirungspraxis unter Geltung des $V G G$, Leck 2018., str. 135; Heine, R., Holzmüller, T., VGG Verwertungsgesselschaftengesetz Kommentar, Leck 2019., §2 Rbr. 20.

50 Tako sa stajališta usporedivog njemačkog prava vidi Heine, R., Holzmüller, T., VGG Verwertungsgesselschaftengesetz, Kommentar, Leck 2019., \$2 Rbr. 21.

${ }_{51}$ Tako sa stajališta usporedivog njemačkog prava vidi Kling, C., Gebietsübergreifende Vergabe von Online-Rechten an Musikwerken, Problemme einer effizienten Lizenzeirungspraxis unter Geltung des $V G G$, Leck 2018., str. 135-136. Pretpostavlja se kako je to rezultat prethodnog zakonskog rješenja prema kojem je povremeno ili kratkotrajno obavljanje djelatnosti kolektivnog ostvarivanja prava bilo izuzeto od dobivanja odobrenja nadležnog regulatora. Sukladno tome nije se isključivala kvalifikacija neke osobe kao organizacije za kolektivno ostvarivanje prava kada je kolektivno ostvarivanje prava bila sporedna, ali trajna svrha takve osobe. U tom smjeru sa stajališta usporedivog njemačkog prava vidi Heine, R., Holzmüller, T., VGG Verwertungsgesselschaftengesetz Kommentar, Leck 2019., §2 Rbr. 20. 
Doc. dr. sc. Tomislav Jakšić: Pojam organizacije za kolektivno ostvarivanje prava i neovisnog upravljačkog... Zbornik radova Pravnog fakulteta u Splitu, god. 58, 3/2021, str. 785-814

pripadnost ili potpadanje pod kontrolu svojih članova te 2) ustrojenost na neprofitnoj osnovi. Takvi su uvjeti prema Direktivi 2014/26/EU, kao i prema VGG-u određeni alternativno. ${ }^{52}$ Drugim riječima, prema europskom i njemačkom pravu, organizacija za kolektivno ostvarivanje prava mora udovoljiti barem jednom od ta dva uvjeta. S druge strane, prema ZAPSP-u, čini se kako su ta dva uvjeta određena kumulativno jer čl. 154. st. 1. t. b) ZAPSP-a određuje kako je organizacija za kolektivno ostvarivanje prava ona "koja: - pripada ili je pod kontrolom svojih članova i ustrojena je na neprofitnoj osnovi". Nije poznato zašto se domaći zakonodavac odlučio za takvo strože rješenje koje ide iznad zahtjeva minimalnog usklađivanja s Direktivom 2014/26/EU koja, ne samo da dopušta alternativitet između tih dviju pretpostavki, već i izričito određuje kako organizacija za kolektivno ostvarivanje prava mora udovoljiti samo jednom od ta dva uvjeta. Takav alternativitet ne isključuje mogućnost svojevoljnog ispunjenja oba uvjeta od strane organizacije. ${ }^{53}$

Uvjet pripadnosti ili potpadanja pod kontrolu svojih članova pravno nije dovoljno precizno određen. Pripadnost se može široko tumačiti, no u predmetnom kontekstu takav se zahtjev tumači tako da članovi moraju držati sve članske udjele u organizaciji za kolektivno ostvarivanje prava. ${ }^{54}$ Takvi članovi mogu biti nositelji autorskih i srodnih prava te osobe koje zastupaju nositelje prava (npr. druge organizacije za kolektivno ostvarivanje prava ili osobe koje zastupaju nositelje prava). ${ }^{55}$ Drugim riječima, članovi udruge ili članovi društva s ograničenom odgovornošću, kao organizacije za kolektivno ostvarivanje prava, mogu biti samo nositelji prava ili druge ovlaštene osobe. ${ }^{56}$

52 Tako prema čl. 3. st. 1. t. a) Direktive 2014/26/EU, organizacija za kolektivno ostvarivanje prava mora ispuniti "jedan ili oba sljedeća kriterija", dok prema odredbi §2 VGG organizacija za kolektivno ostvarivanje prava mora ispuniti "barem jedan od sljedećih uvjeta".

53 Tako sa stajališta usporedivog njemačkog prava vidi Gerlach, T., u: Wandtke, A, Bullinger, W., Urheberrecht, UrhG - KUG - VGG - InfoSoc-RL, Praxiskommentar, 5. Auflage, München 2019., §2 VGG Rbr. 3.

54 Tako vidi odredbu $\$ 2$ VGG prema kojoj članovi organizacije drže sve udjele u toj organizaciji. Za suprotno stajalište koje dijelom počiva na tome što njemačko pravo poznaje i treći način kolektivnog ostvarivanja prava, tzv. ovisni upravljački subjekt (njem. Abhängige Verwertungseinrichtung) prema odredbi §3. VGG, a preko kojeg se može izbjeći primjena strožih pravila koja vrijede za organizacije za kolektivno ostvarivanje prava vidi Kling, C., Gebietsübergreifende Vergabe von Online-Rechten an Musikwerken, Problemme einer effizienten Lizenzeirungspraxis unter Geltung des VGG, Leck 2018., str. 138-139. Takvo stajalište nije primjenjivo na neovisnog upravljačkog subjekta jer je uvjet kvalifikacije za takvu organizaciju nepripadnost i nepostojanje nikakve kontrole nad neovisnim upravljačkim subjektom. Više o tome kasnije pod "4. Pojam neovisnog upravljačkog subjekta". Pritom valja upozoriti kako korišteni izraz iz čl. 3. st. 1. t. a) Direktive 2014/26/EU nije prikladan u hrvatskom pravu kada određuje kako je organizacija u "vlasništvu" svojih članova. Takvo što nije prikladno jer članski udjeli u pravnoj osobi ne mogu biti predmetom vlasništva. Članstvo se u društvu stječe te ga član društva ima zbog čega je član društva samo imatelj članskog (poslovnog) udjela. Shodno tome, ZAPSP umjesto korištenja izraza "vlasništvo" koristi pravilniji izraz "pripadnosti", no još bi prikladnije bilo korištenje izraza "imatelj članskih udjela" koji odgovara izrazu koji u tom pogledu koristi njemačko pravo.

55 Tako vidi čl. 154. st. 1. t. f) ZAPSP-a kao i čl. 3. st. 1. t. d) Direktive 2014/26/EU. Tako sa stajališta usporedivog njemačkog prava vidi Freudenberg, C., u: Ahlberg, H., Götting, H., Urheberrecht, $U r h G-K U G-V e r G-V G G$ Kommentar, 4. Auflage, München 2018., VGG §2 Rbr. 24; Gerlach, T., u: Wandtke, A, Bullinger, W., Urheberrecht, UrhG - KUG - VGG - InfoSoc-RL, Praxiskommentar, 5. Auflage, München 2019., §2 VGG Rbr. 3.

56 Više o zahtjevu koji se odnosi na pravni oblik organizacije za kolektivno ostvarivanje prava vidi kasnije u ovom poglavlju. 
S druge strane, zahtjev kontrole članova treba tumačiti kroz primjenu pravila o povezanim društvima. To znači kako članovi u skupštini organizacije za kolektivno ostvarivanje prava moraju imati većinu udjela ili većinsko pravo odlučivanja (tzv. većinsko sudjelovanje) što im omogućuje kontrolu nad organizacijom, primjerice, krozimenovanje članova organa organizacije. ${ }^{57}$ Pored takvog većinskog sudjelovanja, moguća je uspostava kontrole članova nad organizacijom primjenom drugih pravila o povezanim društvima, npr. pravila o ovisnom i vladajućem društvu pri čemu su članovi vladajućeg društva nositelji prava, a član organizacije je vladajuće društvo.

Izjednačavanje pripadnosti i kontrole ide za obuhvaćanjem svih mogućih situacija u kojima članovi izravno ili neizravno ostvaruju kontrolu. Tako ostvaruju izravnu kontrolu sudjelovanjem u članskoj strukturi organizacije, a neizravnu kontrolu time što sudjelovanjem u članskoj strukturi pravne osobe osnivača organizacije kontroliraju tu pravnu osobu, a koja potom kontrolira organizaciju za kolektivno ostvarivanje prava. ${ }^{58} \mathrm{Iz}$ iznesenog je vidljivo kako navedeni uvjet smjera na to da članovi ili osobe koje kontroliraju organizaciju za kolektivno ostvarivanje prava (u pravilu nositelji prava) budu u mogućnosti, izravno ili neizravno, odlučivati o načinu korištenja prihoda koje takva organizacija ostvaruje kolektivnim ostvarivanjem njihovih prava. ${ }^{59}$

Drugi se uvjet odnosi na zahtjev neprofitnosti organizacije za kolektivno ostvarivanje prava. Drugim riječima, svrha organizacije ne smije biti ostvarivanje dobiti, a prihodi koji budu ostvareni kolektivnim ostvarivanjem prava moraju se raspodijeliti nositeljima prava. ${ }^{60}$ Osim raspodjele nositeljima prava, tako ostvarene prihode organizacija može koristiti samo za namirenje troškova koji nastanu ostvarivanjem tih prava. To ne znači kako organizacija ne može ostvarivati dobit obavljanjem drugih (sporednih) djelatnosti koje se ne kvalificiraju kao kolektivno ostvarivanje prava. ${ }^{61}$

Iz oba zakonska uvjeta proizlazi kako je njihova svrha sprečavanje neisplate prihoda koji su ostvareni kolektivnim ostvarivanjem prava nositeljima prava. ${ }^{62}$ Shodno tome, kako se isti učinak postiže prvim i drugim uvjetom, njihovom kumulacijom ne postiže se ništa što se već ne bi postiglo ispunjenjem jednog od tih

57 Tako vidi čl. 474. st. 1. i st. 2. Zakona o trgovačkim društvima, Narodne novine br. 111/93, $34 / 99$, 121/99, 52/00, 118/03, 107/07, 146/08, 137/09, 125/11, 152/11, 111/12, 68/13, 110/15, 40/19. Tako sa stajališta usporedivog njemačkog prava vidi Heine, R., Holzmüller, T., VGG Verwertungsgesselschaftengesetz. Kommentar, Leck 2019., §2 Rbr. 28.

$58 \mathrm{U}$ tom smjeru sa stajališta usporedivog njemačkog prava vidi Kling, C., Gebietsübergreifende Vergabe von Online-Rechten an Musikwerken, Problemme einer effizienten Lizenzeirungspraxis unter Geltung des VGG, Leck 2018., str. 138.

59 Primjerice, donošenjem pravila o načinu raspodjele prihoda ostvarenih kolektivnim ostvarivanjem prava koja zastupa. Tako vidi čl. 159.c st. 2. i čl. 165.b st. 3. ZAPSP-a.

60 Tako sa stajališta usporedivog njemačkog prava vidi Kling, C., Gebietsübergreifende Vergabe von Online-Rechten an Musikwerken, Problemme einer effizienten Lizenzeirungspraxis unter Geltung des $V G G$, Leck 2018., str. 140.

${ }_{61}$ Tako sa stajališta usporedivog njemačkog prava vidi Heine, R., Holzmüller, T., VGG Verwertungsgesselschaftengesetz, Kommentar, Leck 2019., §2 Rbr. 30.

62 Tako sa stajališta usporedivog njemačkog prava vidi Heine, R., Holzmüller, T., VGG Verwertungsgesselschaftengesetz, Kommentar, Leck 2019., §2 Rbr. 25. 
Doc. dr. sc. Tomislav Jakšić: Pojam organizacije za kolektivno ostvarivanje prava i neovisnog upravljačkog... Zbornik radova Pravnog fakulteta u Splitu, god. 58, 3/2021, str. 785-814

dvaju zahtjeva. S druge strane, takva kumulacija nepotrebno ograničava slobodu uređivanja unutarnjeg ustrojstva organizacije kao i strukture grupe povezanih društava od kojih je jedno društvo organizacija za kolektivno ostvarivanje prava. ${ }^{63}$ Stoga je radi fleksibilizacije takve slobode uređivanja preporučljivo izmijeniti odredbu čl. 154. st. 1.t. b) ZAPSP-a na način da se ta dva zahtjeva odrede alternativno po uzoru na odgovarajuće odredbe Direktive 2014/26/EU i odredbu §2. VGG. Takva bi izmjena omogućila ustrojstvo organizacije na način da njezi ni članovi ne moraju biti ujedno i nositelji prava, ali tada organizacija mora poslovati na neprofitnoj osnovi i obratno. ${ }^{64}$ Pritom bi vjerojatno bilo potrebno odgovarajuće uskladiti i druge odredbe ZAPSP-a o radu pojedinih organa organizacije za kolektivno ostvarivanje prava (npr. opće skupštine). To ne znači da organizacija ne bi mogla ispuniti oba uvjeta, kao što to trenutno nalaže ZAPSP, ali bi tada to bio rezultat slobode uređivanja njezina unutarnjeg ustrojstva od strane ovlaštenih organa organizacije. Neispunjenje niti jednog od navedenih posebnih uvjeta, a ispunjenje ostalih općih uvjeta takvu osobu kvalificira kao neovisnog upravljačkog subjekta. ${ }^{65}$

Zaključno se nameće i pitanje pravnog oblika organizacije za kolektivno ostvarivanje prava. Odredbe koje određuju organizaciju za kolektivno ostvarivanje prava u pravilu ništa ne govore o pravnom obliku takve organizacije. Odredba čl. 3. st. 1. t. a) Direktive 2014/26/EU određuje kako je organizacija za kolektivno ostvarivanje "svaka organizacija" koja ispunjava tom odredbom određene opće i posebne uvjete. Drugim riječima, direktiva ne traži da se organizacija osnuje u nekom određenom pravnom obliku. ${ }^{66}$ Direktiva samo nalaže da korišteni pravni oblik organizacije za kolektivno ostvarivanje prava ne bude prepreka ostvarenju svrhe koja se predmetnom direktivom želi postići (npr. visoki standard upravljanja, transparentnosti i izvještavanja, djelovanje u najboljem zajedničkom interesu nositelja prava koje se zastupa, poseban značaj opće skupštine svih članova organizacije). ${ }^{67}$

Shodno tome, niti ZAPSP ne određuje pravni oblik organizacije za kolektivno ostvarivanje prava. Tako, primjerice, odredba 157. st. 2. ZAPSP-a određuje kako odobrenje za kolektivno ostvarivanje prava može obavljati organizacija

63 Tako prema ZAPSP-u članovi organizacije za kolektivno ostvarivanje prava moraju biti nositelji prava ili osobe koje zastupaju nositelje prava, a ujedno takva organizacija mora poslovati na neprofitnoj osnovi.

$64 \mathrm{U}$ tom smjeru sa stajališta usporedivog njemačkog prava vidi Freudenberg, C., u: Ahlberg, H., Götting, H., Urheberrecht, UrhG - KUG - VerG - VGG Kommentar, 4. Auflage, München 2018., VGG \$2 Rbr. 24-25; Heine, R., Holzmüller, T., VGG Verwertungsgesselschaftengesetz Kommentar, Leck 2019., §2 Rbr. 23.

${ }_{65}$ Više o neovisnom upravljačkom subjektu vidi kasnije pod "4. Pojam neovisnog upravljačkog subjekta".

${ }_{66}$ To potvrđuje i stajalište izneseno u t. 14. preambule Direktive 2014/26/EU. Tamo se, između ostalog, navodi kako organizacije za kolektivno ostvarivanje prava djeluju u različitim pravnim oblicima kao što je udruga, zadruga ili društvo s ograničenom odgovornošću čiji su članovi redovito nositelji autorskih i srodnih prava ili se nalaze pod kontrolom takvih nositelja prava. Štoviše, direktiva navodi kako osobe koje predstavljaju nositelje prava i koje su članovi organizacije za kolektivno ostvarivanje prava mogu biti i druge takve organizacije, udruženja nositelja prava i sl.

${ }^{67}$ Tako vidi, primjerice, t. 9., 23. do 26. preambule Direktive 2014/26/EU. 
Doc. dr. sc. Tomislav Jakšić: Pojam organizacije za kolektivno ostvarivanje prava i neovisnog upravljačkog... Zbornik radova Pravnog fakulteta u Splitu, god. 58, 3/2021, str. 785-814

za kolektivno ostvarivanje prava koje se izdaje udruzi ili drugoj organizaciji za kolektivno ostvarivanje prava. Nije sasvim jasno zašto domaći zakonodavac pridaje značaj udruzi koju izričito navodi kao pravni oblik u kojem može djelovati organizacija za kolektivno ostvarivanje prava jer potom određuje kako to može biti i bilo koji drugi pravni oblik osim udruge. ${ }^{68}$ Pretpostavlja se kako je to stoga da se, iako nepotrebno, legitimira pravni oblik udruge kao trenutno najčešći, ako ne i jedini, pravni oblik u kojem nalazimo domaće organizacije za kolektivno ostvarivanje prava. Takvo posebno tituliranje udruge nije potrebno jer se domaći zakonodavac ionako izričito ne opredjeljuje niti za jedan pravni oblik organizacije za kolektivno ostvarivanje prava te bi radi čistoće i jasnoće zakonskog teksta naznaku "udruge" trebalo ukloniti iz čl. 157. st. 2. ZAPSP-a. To znači kako osnivači organizacije za kolektivno ostvarivanje prava mogu slobodno birati pravni oblik koji najbolje odgovara njihovim potrebama, ali pritom izabrani pravni oblik ne smije biti izgovor toj organizaciji za izbjegavanje ispunjenja posebnih zakonskih obveza koje nalaže ZAPSP. ${ }^{69}$ U Njemačkoj organizacije za kolektivno ostvarivanje prava najčešće nalazimo u pravnom obliku udruge s pravnom osobnošću (njem. rechtsfähigen Verein) ili društva s ograničenom odgovornošću (njem. GmbH) ${ }^{70}$ Upotreba izraza organizacija, kao i zahtjev pripadnosti organizacije članovima ili barem potpadanja organizacije pod kontrolu članova, govori protiv mogućnosti kolektivnog ostvarivanja autorskih i srodnih prava od strane fizičke osobe. ${ }^{71}$

68 Pritom nema osnove za tumačenje kako je udruga jedini pravni oblik u kojem može djelovati organizacija za kolektivno ostvarivanje prava. Nastavak čl. 157. st. 2. ZAPSP-a određuje "... ili drugoj organizaciji za kolektivno ostvarivanje prava koja zadovoljava sljedeće uvjete: a) ima sjedište ili poslovni nastan u Europskoj uniji, b) ima odgovarajuće materijalne i ljudske resurse za obavljanje djelatnosti... c) kolektivno ostvarivanje prava obavlja kao jedinu ili glavnu djelatnost.". Navedeni uvjeti, za koje se može tumačiti kako se primjenjuju na "druge organizacije" (pravnog oblika koji nije udruga) ne isključuju primjenu i na druge pravne oblike organizacije za kolektivno ostvarivanje prava čije je sjedište u Republici Hrvatskoj jer svaka pravna osoba sa sjedištem u Hrvatskoj ima i sjedište ili poslovni nastan u Europskoj uniji. Osim toga, tekst predmetne odredbe omogućuje da se primjena navedenih uvjeta pod a), b) i c) tumači na način da se takvi uvjeti primjenjuju kako na "druge organizacije" tako i na "udruge" koje se također prethodno posebno navode u toj odredbi. Drugim riječima, nema osnove za tumačenje kako organizacije za kolektivno ostvarivanje prava u Hrvatskoj mogu biti samo udruge. To mogu biti i drugi pravni oblici pri čemu je jedino bitno da takve organizacije svojim posebnostima ne ugroze ostvarenje svrhe Direktive 2014/26/EU te da udovolje uvjetima organizacije za kolektivno ostvarivanje prava kao i uvjetima iz čl. 157. st. 2. ZAPSP-a.

${ }_{69}$ Tako sa stajališta usporedivog njemačkog prava vidi Gerlach, T., u: Wandtke, A, Bullinger, W., Urheberrecht, UrhG -KUG -VGG - InfoSoc-RL, Praxiskommentar, 5. Auflage, München 2019., \$2 VGG Rbr. 2.

${ }_{70}$ Tako vidi Freudenberg, C., u: Ahlberg, H., Götting, H., Urheberrecht, UrhG - KUG - VerGVGG Kommentar, 4. Auflage, München 2018., VGG §2 Rbr. 29; Gerlach, T., u: Wandtke, A, Bullinger, W., Urheberrecht, UrhG -KUG - VGG - InfoSoc-RL, Praxiskommentar, 5. Auflage, München 2019., \$2 VGG Rbr. 2; Heine, R., Holzmüller, T., VGG Verwertungsgesselschaftengesetz Kommentar, Leck 2019., \$2 Rbr. 9.

${ }_{71}$ Tako sa stajališta usporedivog njemačkog prava vidi Schulze, G., u: Dreier, T., Schulze, G., Urheberschutzgesetz, 6. Auflage, 2018., VGG §2 Verwertungsgesellschaft Rbr. 2; Freudenberg, C., u: Ahlberg, H., Götting, H., Urheberrecht, UrhG - KUG - VerG - VGG Kommentar, 4. Auflage, München 2018., VGG §2 Rbr. 30; Gerlach, T., u: Wandtke, A, Bullinger, W., Urheberrecht, UrhG - KUG - VGG - InfoSoc-RL, Praxiskommentar, 5. Auflage, München 2019., §2 VGG Rbr. 2; Heine, R., Holzmüller, T., $V G G$ Verwertungsgesselschaftengesetz, Kommentar, Leck 2019., §2 Rbr. 7. 


\section{POJAM NEOVISNOG UPRAVLJAČKOG SUBJEKTA}

Prema čl. 3. st. 1.t. b) Direktive 2014/26/EU, "neovisni upravljački subjekt" znači svaka organizacija koja je u skladu sa zakonom ili prijenosom prava, odobrenjem ili drugim ugovornim sporazumom ovlaštena za upravljanje autorskim ili srodnim pravima u ime više od jednog nositelja prava u zajedničku korist tih nositelja prava kao svojom jedinom i glavnom svrhom i koja: i) nije niti u vlasništvu niti pod nadzorom, u cijelosti ili djelomičnom, nositelja prava; te ii) ustrojena je na profitnoj osnovi. S druge strane, prema čl. 154. st. 1. t. d) ZAPSP-a, "neovisni upravljački subjekt" jest svaka organizacija koja je na temelju zakona ili ugovora ovlaštena ostvarivati autorska ili srodna prava za dva ili više nositelja prava neovisno o tome djeluje li u svoje ime ili u ime nositelja prava, za njihovu zajedničku korist, kojoj je to jedina ili glavna svrha i koja: ni u cijelosti ni u dijelu ne pripada svojim članovima, niti je pod njihovom kontrolom, bilo direktno bilo indirektno te je ustrojena na profitnoj osnovi.

Usporedbom takvog određenja "neovisnog upravljačkog subjekta" s određenjem "organizacije za kolektivno ostvarivanje prava" iz čl. 3. st. 1. t. a) Direktive 2014/26/ EU i čl. 154. st. 1. t. b) ZAPSP-a, uočljivo je kako se sadržaj definicije neovisnog upravljačkog subjekta u velikoj mjeri preklapa sa sadržajem definicije organizacije za kolektivno ostvarivanje prava. To izričito potvrđuje i odredba §4. VGG-a prema kojoj neovisni upravljački subjekt, pored općih uvjeta koji se primjenjuju na organizaciju za kolektivno ostvarivanje prava, mora ispuniti i dva posebna uvjeta. Organizacija za kolektivno ostvarivanje prava i neovisni upravljački subjekt stoga predstavljaju dva različita načina kolektivnog ostvarivanja autorskih i srodnih prava. ${ }^{72}$ Upravo stoga što se radi o dva različita načina kolektivnog ostvarivanja prava logično je kako između ta dva načina kolektivnog ostvarivanja prava mora postojati i neka razlika.

Neovisni upravljački subjekt tako ponajprije mora kumulativno ispuniti opće uvjete kojima mora udovoljiti i organizacija za kolektivno ostvarivanje prava. To je uvjet: 1) ostvarivanja autorskih i srodnih prava, 2) kolektivnog ostvarivanja prava za više nositelja prava, 3) ostvarivanja prava za zajedničku korist (račun) nositelja prava te 4) kolektivnog ostvarivanja autorskih i srodnih prava kao jedine ili glavne svrha takve organizacije. ${ }^{73} \mathrm{U}$ pogledu sadržaja navedenih općih uvjeta upućuje se na jednako primjenjiva ranija pojašnjenja tih uvjeta u pogledu organizacije za kolektivno ostvarivanje prava. ${ }^{74}$ Kao i kod organizacije za kolektivno ostvarivanje prava, niti za neovisni upravljački subjekt mjerodavne odredbe ne nalažu upotrebu

72 Tako sa stajališta usporedivog njemačkog prava vidi Heine, R., Holzmüller, T., VGG Verwertungsgesselschaftengesetz, Kommentar, Leck 2019., §4 Rbr. 1.

73 Tako sa stajališta usporedivog njemačkog prava vidi Freudenberg, C., u: Ahlberg, H., Götting, H., Urheberrecht, UrhG - KUG - VerG - VGG Kommentar, 4. Auflage, München 2018., VGG $\$ 4$ Rbr. 2-3; Freudenberg, C., u: Alhberg, H., Götting, H., BeckOK Urheberrecht, 23. Auflage, VGG §4 Unabhängige Verwertungseinrichtungen Rbr. 7; Gerlach, T., u: Wandtke, A, Bullinger, W., Urheberrecht, UrhG KUG - VGG - InfoSoc-RL, Praxiskommentar, 5. Auflage, München 2019., §4 VGG Rbr. 2; Heine, R., Holzmüller, T., VGG Verwertungsgesselschaftengesetz, Kommentar, Leck 2019., §4 Rbr. 6.

${ }_{74}$ Tako vidi ranije pod poglavljem "3. Pojam organizacije za kolektivno ostvarivanje prava". 
Doc. dr. sc. Tomislav Jakšić: Pojam organizacije za kolektivno ostvarivanje prava i neovisnog upravljačkog... Zbornik radova Pravnog fakulteta u Splitu, god. 58, 3/2021, str. 785-814

određenog pravnog oblika. ${ }^{75}$ Tako identično kao i kod organizacije za kolektivno ostvarivanje prava čl. 3. st. 1. t. b) Direktive 2014/26/EU određuje kako je neovisni upravljački subjekt "svaka organizacija" koja ispunjava određene opće i posebne uvjete. Po uzoru na takvo određenje direktive, čl. 154. st. 1. t. d) ZAPSP-a jednako tako određuje kako je neovisni upravljački subjekt "svaka organizacija" koja ispunjava određene opće i posebne uvjete. Kasnije odredbe ZAPSP-a također ne određuju pravni oblik neovisnog upravljačkog subjekta zbog čega se može zaključiti kako neovisni upravljački subjekt može djelovati u bilo kojem pravnom obliku. ${ }^{76}$ Prema tome, neovisni upravljački subjekt u pravilu može djelovati u bilo kojem pravnom obliku, no to će najčešće biti neki oblik trgovačkog društva kao što je društvo s ograničenom odgovornošću (npr. Soundreef Ltd., Jamendo Licensing, CCLI Lizenzagentur GmbH).

Za razliku od čl. 154. st. 1. t. b) ZAPSP-a, t. d) iste odredbe ZAPSP-a posebno navodi primjere osoba koje se ne smatraju neovisnim upravljačkim subjektom. Tako predmetna odredba određuje kako se neovisnim upravljačkim subjektima ne smatraju producenti, organizacije za radiofuziju, nakladnici koji ostvaruju vlastita prava kao i prava drugih nositelja prava prenesena pojedinačnim sporazumima koji djeluju u vlastitom interesu, a potom ni menadžeri i agenti nositelja prava koji djeluju kao posrednici i zastupaju nositelje prava u njihovim odnosima s organizacijama za kolektivno ostvarivanje prava. To stoga što producenti, organizacije za radiofuziju i nakladnici ostvaruju autorska i srodna prava "za svoj račun djelujući u vlastitom interesu", a ne za račun autora i nositelja srodnih prava. ${ }^{77} \mathrm{~S}$ druge strane, menadžeri i agenti nositelja prava pored toga djeluju i kao posrednici te zastupnici nositelja autorskih i srodnih prava pri čemu oni ne određuju cijene, izdaju odobrenja ili naplaćuju naknadu za iskorištavanje takvih prava kao što to čine neovisni upravljački subjekti. ${ }^{78}$ Vidljivo kako su u oba slučaja navedeni razlozi koji isključuju navedene kategorije iz kvalifikacije kao neovisne upravljačke subjekte, a koji su primjenjivi i na organizacije za kolektivno ostvarivanje prava, tj. ostvarivanje prava za račun nositelja prava te određivanje naknade, izdavanje odobrenja i naplata naknade za iskorištavanje autorskih i srodnih prava. ${ }^{79}$ Prema tome, ostvarivanje autorskih i srodnih prava za svoj račun isključuje mogućnost kvalifikacije za neovisnog upravljačkog subjekta. Pored toga, takvo određivanje

75 Tako sa stajališta usporedivog njemačkog prava vidi Heine, R., Holzmüller, T., VGG Verwertungsgesselschaftengesetz, Kommentar, Leck 2019., §4 Rbr. 7.

76 Time više što Direktiva 2014/26/EU i ZAPSP za neovisnog upravljačkog subjekta ne određuju posebna pravila u pogledu unutarnjeg ustrojstva i djelovanja kao što je to, primjerice, određeno kod organizacije za kolektivno ostvarivanje prava (npr. u pogledu osoba koje upravljaju organizacijom, tijela koje ima nadzornu funkciju i opće skupštine svih članova organizacije). Iz toga je vidljivo kako su zahtjevi u pogledu zaštite ostvarenja svrhe koja se želi postići Direktivom 2014/26/EU puno manji u odnosu na neovisnog upravljačkog subjekta, tj. puno je manja mogućnost da će izbor određenog pravnog oblika ugroziti ostvarenje takve svrhe. Više o tome vidi pri kraju ovog poglavlja gdje se ukratko obrazlažu gospodarska uloga i narav neovisnog upravljačkog subjekta.

77 Tako vidi t. 16. preambule Direktive 2014/26/EU.

78 Tako vidi t. 16. preambule Direktive 2014/26/EU.

79 Tako sa stajališta usporedivog njemačkog prava vidi Freudenberg, C., u: Ahlberg, H., Götting, H., Urheberrecht, UrhG-KUG-VerG-VGG Kommentar, 4. Auflage, München 2018., VGG $\$ 4$ Rbr. 7. 
Doc. dr. sc. Tomislav Jakšić: Pojam organizacije za kolektivno ostvarivanje prava i neovisnog upravljačkog... Zbornik radova Pravnog fakulteta u Splitu, god. 58, 3/2021, str. 785-814

naknade, izdavanje odobrenja ili naplaćivanje naknade za korištenje autorskih i srodnih prava od korisnika treba tumačiti u smislu zakonom propisanih ovlasti i obveza organizacije za kolektivno ostvarivanje prava te neovisnog upravljačkog subjekta. ${ }^{80}$ Upravo je kolektivno ostvarivanje autorskih prava za račun nositelja prava ključna pretpostavka obavljanja takve djelatnosti, a time i kvalifikacije nekog subjekta kao organizacije za kolektivno ostvarivanje prava ili neovisnog upravljačkog subjekta. Bez takvog načina ostvarivanja autorskih prava ne bi bilo potrebe za ograničavanjem djelatnosti navedenih subjekata niti za obavljanjem nadzora nad kolektivnim ostvarivanjem prava od strane nadležnog regulatora. ${ }^{81}$ Stoga dio odredbe čl. 154. st. 1.t. d) ZAPSP-a koji isključuje kvalifikaciju određenih kategorija osoba za neovisnog upravljačkog subjekta treba ukloniti iz te odredbe te ga navesti u posebnu odredbu koja se odnosi i na organizaciju za kolektivno ostvarivanje prava jer trenutno rješenje stvara pogrešnu predodžbu kako se navedene kategorije osoba samo ne mogu kvalificirati kao neovisni upravljački subjekt, a ne i organizacije za kolektivno ostvarivanje prava. ${ }^{82}$

Pored navedenih općih uvjeta, neovisni upravljački subjekt mora ispuniti i dva posebna uvjeta po kojima se neovisni upravljački subjekt razlikuje od organizacije za kolektivno ostvarivanje prava. ${ }^{83}$ Tako prema čl. 154. st. 1. t. d) ZAPSP-a, neovisni upravljački subjekt: 1) ne smije pripadati u cijelosti niti djelomično članovima, a ne smije biti niti pod njihovom izravnom ili neizravnom kontrolom, 2) a njegovo poslovanje pritom mora biti usmjereno na ostvarivanje dobiti. ${ }^{84}$ Izneseno u pogledu pripadnosti i kontrole znači kako se neka osoba može kvalificirati kao neovisni upravljački subjekt tek kada osobe iz čl. 154. st. 1. t. f) ZAPSP-a nisu članovi neovisnog upravljačkog subjekta niti takve osobe, u potpunosti ili djelomično,

80 Tako, primjerice, vidi čl. 165. ZAPSP-a o načelima za određivanje visine naknade korištenja predmeta zaštite, čl. 160. ZAPSP-a o davanju odobrenja za korištenje predmeta zaštite te čl. 165.b ZAPSP-a o naplati i korištenju prihoda od prava.

${ }_{81}$ Tako sa stajališta usporedivog njemačkog prava vidi Freudenberg, C., u: Alhberg, H., Götting, H., BeckOK Urheberrecht, 24. Auflage, VGG §2 Verwertungsgesselschaft Rbr. 20.

82 Takvu kvalifikaciju određenih kategorija osoba moguće je navesti u obrazloženju odredaba ZAPSP-a kojima se određuje pojam organizacije za kolektivno ostvarivanje prava i neovisnog upravljačkog subjekta. Ipak se radi pravne sigurnosti predlaže takvo isključenje kvalifikacije kategorija osoba navesti kao posebnu odredbu ZAPSP-a sukladno danom prijedlogu koji prati ova fusnota.

83 Tako sa stajališta usporedivog njemačkog prava Freudenberg, C., u: Ahlberg, H., Götting, H., Urheberrecht, UrhG - KUG - VerG - VGG Kommentar, 4. Auflage, München 2018., VGG §4 Rbr. 4; Gerlach, T., u: Wandtke, A, Bullinger, W., Urheberrecht, UrhG - KUG - VGG - InfoSoc-RL, Praxiskommentar, 5. Auflage, München 2019., §4 VGG Rbr. 2.

${ }_{84}$ Za razliku od neovisnog upravljačkog subjekta, prema čl. 154. st. 1. t. b) ZAPSP-a, organizacija za kolektivno ostvarivanje prava mora pripadati ili biti pod kontrolom "svojih" članova te biti ustrojena na neprofitnoj osnovi. Ovdje pritom valja upozoriti na grešku koja postoji u tekstu čl. 154. st. 1. t. d) ZAPSP-a tako što se navodi kako ne smije pripadati "svojim" članovima. Takvo korištenje izraza upućuje na zaključak kako nositelji prava mogu biti članovi neovisnog upravljačkog subjekta, što je pogrešno. Upravo je naglasak na tome da nositelji prava i druge ovlaštene osobe iz čl. 154. st. 1. t. f) ZAPSP-a ne mogu biti članovi neovisnog upravljačkog subjekta. Tako vidi čl. 3. st. 1. t. b) Direktive 2014/26/EU koja navodi kako neovisni upravljački subjekt ne smije biti u vlasništvu niti pod nadzorom, u "cijelosti ili djelomično", nositelja prava. Stoga je iz navedene definicije pojma neovisnog upravljačkog subjekta potrebno brisati izraz "svojim". 
ostvaruju kontrolu nad tom organizacijom. ${ }^{85}$ Usmjerenosti na ostvarivanje dobiti ne znači da neovisni upravljački subjekt mora faktično i ostvarivati dobit, već samo kako se djelatnost kolektivnog ostvarivanja prava obavlja radi ostvarivanja dobiti. Ako osoba ispunjava sve opće i posebne uvjeta osim uvjeta usmjerenosti na ostvarivanje dobiti, ona se kvalificira kao organizacija za kolektivno ostvarivanje prava, a ne kao neovisni upravljački subjekt. Tek kada neka osoba udovolji svim općim i posebnim uvjetima, kvalificira se kao neovisni upravljački subjekt. ${ }^{86}$

Imajući u vidu navedena svojstva neovisnog upravljačkog subjekta, može se zaključiti kako je neovisni upravljački subjekt, za razliku od organizacije za kolektivno ostvarivanje prava, gospodarski subjekt koji aktivno sudjeluje na tržištu radi ostvarivanja dobiti obavljajući djelatnost kolektivnog ostvarivanja autorskih i srodnih prava za račun nositelja takvih prava. Pritom se članska struktura neovisnog upravljačkog subjekta sastoji od osoba koje nisu nositelji autorskih i srodnih prava, a takva organizacija ne može biti niti pod kontrolom nositelja prava. ${ }^{87}$ Kako bi obavljao takvu djelatnost, neovisni upravljački subjekt redovito ulazi u ugovorne odnose s pojedinim nositeljima prava ili osobama koje zastupaju nositelje prava (npr. organizacijama za kolektivno ostvarivanje prava, menadžerima ili agentima). Temeljem tog ugovora neovisni upravljački subjekt stječe mogućnost kolektivnog ostvarivanja određenih prava na području jedne ili više država, a zauzvrat se obvezuje tako ostvareni prihod raspodijeliti nositeljima prava koje zastupa. Nakon toga neovisni upravljački subjekt sklapa s pojedinim korisnicima ugovore o iskorištavanju takvih autorskih i srodnih prava (tzv. autorskopravni ugovor) koje kolektivno zastupa. Neovisni upravljački subjekt takve ugovore sklapa u svoje ime ili u ime nositelja prava, ali uvijek za račun (zajedničku korist) nositelja prava koje zastupa ${ }^{88}$ Takvo kolektivno ostvarivanje prava pritom predstavlja jedinu ili glavnu djelatnost neovisnog upravljačkog subjekta. Međutim, neovisni upravljački subjekt u bitnome se razlikuje od organizacije za kolektivno ostvarivanje prava po tome što je takvo ostvarivanje prava upravo usmjereno na ostvarivanje dobiti. Unatoč tome što kolektivno ostvaruje autorska i srodna prava za nositelje tih prava, neovisni upravljački subjekt ima pravo na određeni udio (proviziju) u naknadama koje naplati od korisnika obavljajući djelatnost kolektivnog ostvarivanja prava nositelja koje zastupa (npr. s naslova ugovora o iskorištavanju autorskog djela sa svakim pojedinim

$85 \mathrm{U}$ tom smjeru sa stajališta usporedivog njemačkog prava vidi Kling, C., Gebietsübergreifende Vergabe von Online-Rechten an Musikwerken, Problemme einer effizienten Lizenzeirungspraxis unter Geltung des VGG, Leck 2018., str. 139; Heine, R., Holzmüller, T., VGG Verwertungsgesselschaftengesetz Kommentar, Leck 2019., §4 Rbr. 9.

86 Tako sa stajališta usporedivog njemačkog prava vidi Freudenberg, C., u: Alhberg, H., Götting, H., BeckOK Urheberrecht, 23. Auflage, VGG \$4 Unabhängige Verwertungseinrichtungen Rbr. 4; Freudenberg, C., u: Ahlberg, H., Götting, H., Urheberrecht, UrhG - KUG - VerG - VGG Kommentar, 4. Auflage, München 2018., VGG §4 Rbr. 4.

${ }_{87}$ Tako sa stajališta usporedivog njemačkog prava vidi Kling, C., Gebietsübergreifende Vergabe von Online-Rechten an Musikwerken, Problemme einer effizienten Lizenzeirungspraxis unter Geltung des $V G G$, Leck 2018., str. 164.

${ }_{88}$ Tako sa stajališta usporedivog njemačkog prava vidi Freudenberg, C., u: Alhberg, H., Götting, H., BeckOK Urheberrecht, 23. Auflage, VGG §4 Unabhängige Verwertungseinrichtungen Rbr. 4. 
Doc. dr. sc. Tomislav Jakšić: Pojam organizacije za kolektivno ostvarivanje prava i neovisnog upravljačkog... Zbornik radova Pravnog fakulteta u Splitu, god. 58, 3/2021, str. 785-814

korisnikom). ${ }^{89}$ Iako je svrha neovisnog upravljačkog subjekta raspodjela iznosa ostvarenih kolektivnim ostvarivanjem prava, to nije jedina svrha jer takva svrha ima i trgovačku (profitnu) dimenziju. Iz toga proizlazi kako poslovni model neovisnog upravljačkog subjekta mora biti financijski atraktivniji pojedinim nositeljima prava nego što je to model koji nude tradicionalne organizacije za kolektivno ostvarivanje prava, a sve kako bi potakli pojedine nositelje prava da povuku ovlasti koje su dali organizaciji za kolektivno ostvarivanje prava i kolektivno ostvarivanje svojih prava prepuste neovisnom upravljačkom subjektu. Pretpostavlja se kako neovisni upravljački subjekti takvu atraktivnost postižu većom racionalizacijom poslovanja, fokusiranjem na isplative kategorije kolektivnog ostvarivanja autorskih i srodnih prava te nižim troškovima poslovanja uslijed smanjenog regulatornog nadzora..$^{90}$ Time neovisni upravljački subjekt predstavlja izravnu konkurenciju monopolu odnosno vladajućem tržišnom položaju organizacije za kolektivno ostvarivanje prava koja ostvaruje ista prava kao i neovisni upravljački subjekt. Pretpostavlja se kako je suzbijanje i narušavanje takvog monopola i vladajućeg položaja bio jedan od razloga zašto se europski zakonodavac odlučio za uvođenje novog modela kolektivnog ostvarivanja prava na prostoru Europske unije kroz neovisni upravljački subjekt.

\section{NEOVISNI UPRAVLJAČKI SUBJEKT PREMA NACRTU NOVOG PRIJEDLOGA ZAKONA}

Neposredno prije pisanja ovog rada u javnoj raspravi nalazio se nacrt novog prijedloga Zakona o autorskom pravu i srodnim pravima (dalje: NPZAPSP). ${ }^{91}$ Iako je fokus izmjena tog prijedloga usmjeren na dio zakona o iskorištavanju autorskih i srodnih prava, zakonodavac u obrazloženju određuje kako također koristi ovu priliku za "detaljnije uređenje uvjeta za obavljanje djelatnosti kolektivnog ostvarivanja prava od strane neovisnih upravljačkih subjekata". To stoga što su "nedostaci zamijećeni u primjeni dosadašnjeg propisa, što će dovesti do veće

89 U tom smjeru sa stajališta usporedivog njemačkog prava vidi Schulze, G., u: Dreier, T., Schulze, G., Urheberschutzgesetz, 6. Auflage, 2018., VGG §4 Verwertungsgesellschaft Rbr. 2, 4. Primjerice tako Soundreef Ltd. zadržava polovinu od naplaćene naknade nakon oporezivanja za iskorištavanje predmeta zaštite, a drugu polovicu isplaćuje nositelju prava. Tako vidi Kling, C., Gebietsübergreifende Vergabe von Online-Rechten an Musikwerken, Problemme einer effizienten Lizenzeirungspraxis unter Geltung des $V G G$, Leck 2018., str. 165.

90 Soundreef Ltd. tako, primjerice, svjesno ne raspolaže jednako opsežnim repertoarom autorskih djela kao organizacije za kolektivno ostvarivanje prava. To je stoga što Soundreef Ltd. bira kojim će se nositeljima prava obratiti radi kolektivnog ostvarivanja prava na tržištu izvođenja pozadinske glazbe $u$ pojedinim trgovinama. Stoga, za razliku od organizacije za kolektivno ostvarivanje prava, kod neovisnog upravljačkog subjekta ne postoji sloboda izbora organizacije za kolektivno ostvarivanje prava jer neovisni upravljački subjekt ne mora pristati na ponudu za kolektivno ostvarivanje prava od strane nositelja prava. Tako vidi Kling, C., Gebietsübergreifende Vergabe von Online-Rechten an Musikwerken, Problemme einer effizienten Lizenzeirungspraxis unter Geltung des VGG, Leck 2018., str. 165.

${ }_{91}$ Tako vidi na web-stranici e-savjetovanja (https://esavjetovanja.gov.hr/Econ/MainScreen? entityId=13850), 15. lipnja 2020. Nacrt novog prijedloga zakona nalazio se u javnoj raspravi do 17. svibnja 2020. pri čemu su zainteresirane osobe dale preko 300 komentara. 
Doc. dr. sc. Tomislav Jakšić: Pojam organizacije za kolektivno ostvarivanje prava i neovisnog upravljačkog... Zbornik radova Pravnog fakulteta u Splitu, god. 58, 3/2021, str. 785-814

jasnoće i jednostavnije primjene Zakona". ${ }^{92}$ Shodno tome, ovo poglavlje razmatra prijedlog tih novih odredaba NPZAPSP-a koje se odnose na određenje pojma neovisnog upravljačkog subjekta i kolektivno ostvarivanje prava. Tako čl. 207. st. 2. i st. 4. NPZAPSP-a određuje pojam organizacije za kolektivno ostvarivanje prava i neovisnog upravljačkog subjekta. Pritom navedeni pojmovi sadržajno ne odudaraju od pojmova tih organizacija prema važećim odredbama čl. 154. st. 1. t. b) i d) ZAPSP-a. ${ }^{93}$

U odnosu na ZAPSP, iz definicije pojma neovisnog upravljačkog subjekta NPZAPSP izbacuje navođenje kategorija osoba koje se na smatraju neovisnim upravljačkim subjektom. Navođenje tih kategorija osoba prebačeno je u posebnu odredbu čl. 207. st. 6. NPZAPSP-a, međutim, i dalje bez naznake kako se to primjenjuje $\mathrm{i}$ na organizaciju za kolektivno ostvarivanje prava. ${ }^{94}$ Također pri određivanju pojma organizacije za kolektivno ostvarivanje prava i neovisnog upravljačkog subjekta zakonske definicije prikladno je proširiti dodavanjem izraza "za račun više nositelja prava". Time više što je takva naznaka pravne naravi kolektivnog ostvarivanja prava izričito naznačena kasnijim odredbama čl. 215. st. 7. i čl. 216. st. 10. NPZAPS-a. Takva narav djelatnosti kolektivnog ostvarivanja prava od velikog je značaja za kvalifikaciju kolektivnog ostvarivanja prava u odnosu na ostale mogućnosti ostvarivanja prava zbog čega joj treba dati potrebnu vidljivost. To ne znači kako i druge osobe ne mogu ostvarivati prava za račun nositelja prava, no tada će kvalifikacija takvog ostvarivanja prava za račun nositelja prava, kao kolektivnog ostvarivanja prava, ovisiti o ispunjenju drugih općih i posebnih uvjeta organizacije za kolektivno ostvarivanje prava ili neovisnog upravljačkog subjekta. ${ }^{95}$

Iako se novim prijedlogom zakona u pogledu određivanja pojma neovisnog upravljačkog subjekta ništa značajno ne mijenja u odnosu na postojeće zakonsko rješenje, novim prijedlogom zakona predlažu se značajnije izmjene u pogledu dodatnih uvjeta potrebnih za obavljanje djelatnosti kolektivnog ostvarivanja prava od strane neovisnog upravljačkog subjekta. Tako čl. 216. st. 2. NPZAPSP-a određuje kako neovisni upravljački subjekt sa sjedištem ili poslovnim nastanom u Hrvatskoj mora dobiti odobrenje nadležnog regulatora za obavljanje djelatnosti kolektivnog ostvarivanja prava. Time se ponajprije odstupa od pravila iz čl.

92 Tako vidi pod ii. Ocjenu stanja i osnovna pitanja koja se uređuju predloženim zakonom te posljedice koje će donošenjem zakona proisteći NZAPSP, str. 4.

93 Niti novi prijedlog odredbe čl. 207. st. 2. NPZAPSP-a kao niti odgovarajuća odredba čl. 154. st. 1. t. b) ZAPSP-a ne određuju posebne uvjete alternativno, već kumulativno. Shodno tome, posebne uvjete za obavljanje djelatnosti kolektivnog ostvarivanja prava od strane organizacije za kolektivno ostvarivanje prava valja odrediti alternativno iz istih razloga koji su navedeni ranije u tekstu. Više o tome vidi pod "3. Pojam organizacije za kolektivno ostvarivanje prava". Novi prijedlog čl. 207. st. 5. NPZAPSP-a, kao i čl. 154. st. 1. t. d) ZAPSP-a kojim se određuje pojam neovisnog upravljačkog subjekta kod navođenja prvog posebnog uvjeta koristi izraz "svojim" članovima. Kao što je prethodno obrazloženo, to upućuje na zaključak kako nositelji prava mogu biti članovi neovisnog upravljačkog subjekta, što nije točno. Shodno tome, iz predmetne odredbe NPZAPSP-a treba brisati izraz "svojim". Više o tome vidi pod "4. Pojam neovisnog upravljačkog subjekta".

94 Više o tome vidi ranije u tekstu pod "4. Pojam neovisnog upravljačkog subjekta".

95 Više o tome vidi ranije u tekstu pod "3. Pojam organizacije za kolektivno ostvarivanje prava" te "4. Pojam neovisnog upravljačkog subjekta". 
Doc. dr. sc. Tomislav Jakšić: Pojam organizacije za kolektivno ostvarivanje prava i neovisnog upravljačkog... Zbornik radova Pravnog fakulteta u Splitu, god. 58, 3/2021, str. 785-814

171.b st. 1. ZAPSP-a, ali i rješenja poredbenog prava (vidi §91. st. 2. VGG-a i tzv. Anzeigepflicht), prema kojem je dovoljno obavještavanje o namjeri obavljanja djelatnosti kolektivnog ostvarivanja prava od strane neovisnog upravljačkog subjekta. To znači kako je za obavljanje djelatnosti kolektivnog ostvarivanja prava od strane neovisnog upravljačkog subjekta bilo dovoljno obavještavanje DZIV-a o toj namjeri bez potrebe prethodnog certificiranja od strane regulatora. ${ }^{96}$ Prema novom prijedlogu, neovisni upravljački subjekt mora dobiti odobrenje DZIV-a kako bi mogao obavljao djelatnost kolektivnog ostvarivanja prava, pri čemu mora udovoljiti određenim materijalnim, tehničkim i kadrovskim uvjetima iz čl. 216. st. 4. i 5. NPZAPSP-a. Takvi su uvjeti određeni poprilično apstraktno (npr. poslovni prostor opremljen informatičkom i komunikacijskom opremom "primjerenom" za ispunjavanje propisanih obveza) zbog čega ne pružaju potrebnu pravnu sigurnost adresatima koji žele djelovati kao neovisni upravljački subjekt. ${ }^{97}$

Izneseni problem promjene načina registracije za obavljanje djelatnosti neovisnog upravljačkog subjekta time postaje veći uzme li se u obzir čl. 216. st. 16. ZAPSP-a prema kojem, u slučaju odbijanja zahtjeva za davanje odobrenja za obavljanje djelatnosti kolektivnog ostvarivanja prava kao neovisni upravljački subjekt, podnositelj zahtjeva "ne može podnijeti novi zahtjev prije proteka pet godina od podnošenja" prvotnog zahtjeva. Takva zabrana je neproporcionalna i neprimjerena onome što bi trebao biti smisao pribavljanja prethodno odobrenja i takve zabrane ponovljenog podnošenja zahtjeva do proteka određenog vremena, a to je osigurati vrijeme koje je razumno potrebno da se nakon odbijanja prvotnog zahtjeva naknadno osiguraju odgovarajući tehnički i kadrovski uvjeti za obavljanje djelatnosti kolektivnog ostvarivanja prava. Pet godina je predugo vrijeme za takvo što zbog čega izneseno pravilo govori u prilog gospodarski neutemeljene, pravno neosnovane pa čak i protuzakonite zaštite tržišnih pozicija postojećih organizacija za kolektivno ostvarivanje prava, ponajprije sa stajališta pravila kojima se uređuje tržišno natjecanje, a potom i Direktive 2014/26/EU. Svrha te direktive i pravila uvođenju neovisnog upravljačkog subjekta upravo je pružanje izbora nositeljima prava i korisnicima između novog načina za kolektivno ostvarivanje prava preko neovisnog upravljačkog subjekta i tradicionalnog načina kolektivnog ostvarivanja prava preko organizacije za kolektivno ostvarivanje prava. Petogodišnja zabrana

96 Više o tome sa stajališta usporedivog njemačkog prava vidi Freudenberg, C., u: Ahlberg, H., Götting, H., Urheberrecht, UrhG -KUG - VerG - VGG Kommentar, 4. Auflage, München 2018., VGG \$91 Rbr. 9-13; Heine, R., Holzmüller, T., VGG Verwertungsgesselschaftengesetz Kommentar, Leck 2019., \$91 Rbr. 13-14, 16.

97 Tako, primjerice, iz navedene odredbe nije vidljivo o kakvom i o kojoj veličini poslovnog prostora jest riječ te koja je to informatička i komunikacija oprema dostatna za obavljanje djelatnosti kolektivnog ostvarivanja prava od strane neovisnog upravljačkog subjekta. Je li to ista razina kojoj moraju udovoljiti i organizacije za kolektivno ostvarivanje prava ili neka druga razine materijalne, kadrovske i tehničke dostatnosti? Pritom primjena istih uvjeta koji se odnose na organizacije za kolektivno ostvarivanje prava nije prikladna jer je djelatnost kolektivnog ostvarivanja prava od strane neovisnog upravljačkog subjekta opsegom u pravilu bitno manja od djelatnosti koju obavljaju organizacije za kolektivno ostvarivanje prava. Takvi uvjeti, ako se zakonodavac odluči za njihovo zadržavanje, što se ne preporuča iz razloga koji se daju u nastavku teksta, moraju biti jasno konkretizirani da onemoguće ili barem bitno smanje diskrecijsku procjenu regulatora i pruže potrebnu pravnu sigurnost svima koji žele obavljati djelatnost neovisnog upravljačkog subjekta. 
Doc. dr. sc. Tomislav Jakšić: Pojam organizacije za kolektivno ostvarivanje prava i neovisnog upravljačkog... Zbornik radova Pravnog fakulteta u Splitu, god. 58, 3/2021, str. 785-814

podnošenja novog zahtjeva zajedno s izrazito apstraktno određenim uvjetima za dobivanje tog odobrenja bitno otežava ulazak potencijalnih novih sudionika na tržište kolektivnog ostvarivanja prava u Hrvatskoj. Takvo rješenje ponajprije nije u skladu sa zahtjevima direktive jer narušava njezinu svrhu (liberalizacija tržišta za kolektivno ostvarivanje prava), a time i tržišno natjecanje jer pridonosi održavanju monopola i vladajućeg položaja postojećih organizacija za kolektivno ostvarivanje prava. $^{98}$

Prethodno izneseno, međutim, ne znači kako je predloženi model prethodnog odobrenja za obavljanje djelatnosti kolektivnog ostvarivanja prava od strane neovisnog upravljačkog subjekta odgovarajuće rješenje. Nameće se pitanje zašto se domaći zakonodavac uopće opredjeljuje za takvo rješenje jer se stječe dojam da se pribojava djelatnosti neovisnog upravljačkog subjekta. Pritom valja naglasiti kako niti jedna takva organizacija do danas nije formalno registrirana za obavljanje djelatnosti kolektivnog ostvarivanja prava u Hrvatskoj zbog čega nije jasno od kuda potiču takvi strahovi. ${ }^{99}$ Namećući dodatne uvjete za obavljanje takve djelatnosti domaći zakonodavac samo neosnovano otežava pristup tržištu kolektivnog ostvarivanja prava. U tom pogledu, svakako se predlaže korištenje njemačkog pristupa koji zagovara i aktualni ZAPSP, a to je obveza prethodnog obavještavanja nadležnog regulatora o namjeri obavljanja djelatnosti neovisnog upravljačkog subjekta. Takvo rješenje, ne samo da je u skladu s ciljem i svrhom europskog prava, već je i u skladu s njemačkim pravom koje nam u mnogočemu, pa i u ovom pogledu, može biti uzor. Odgovarajuća zaštita interesa nositelja prava i korisnika osigurava se naknadnim inspekcijskim nadzorom nad neovisnim upravljačkim subjektom, ali i individualnom zaštitom nositelja koja počiva na povredi ugovorene obveze od strane neovisnog upravljačkog subjekta. Takvi mehanizmi pružaju odgovarajuću zaštitu nositeljima prava, a pritom im pružaju i izbor glede načina na koji će se kolektivno ostvarivati takva prava. ${ }^{100}$ Pritom ne treba zaboraviti kako nositelji prava i korisnici uvijek imaju mogućnost izbora korištenja usluga organizacije za kolektivno ostvarivanje prava. Ako su nezadovoljni uslugom koju, primjerice, pruža organizacija za kolektivno ostvarivanje prava, mogu se obratiti odgovarajućem neovisnom upravljačkom subjektu ako takav postoji na tržištu i obratno. Postojanje

98 Tako, primjerice, t. 15. preambule Direktive 2014/26/EU određuje kako "nositelji prava trebali bi biti slobodni da upravljanje svojim pravima povjere neovisnim subjektima za upravljanje". Nositelji prava neće imati tu mogućnost ako zakonodavac odredbama NPZAPSP-a odredi prestroge i diskrecijske uvjete za obavljanje djelatnosti neovisnog upravljačkog subjekta, a svakako kada u slučaju odbijanja zahtjeva za davanjem odobrenja odredi zabranu podnošenja novog zahtjeva za davanjem odobrenja u trajanju od pet godina.

99 Informacije na web-stranicama DZIV-a ne pokazuju kako se ijedan neovisni upravljački subjekt prijavio za obavljanje djelatnosti kolektivnog ostvarivanja prava u Hrvatskoj u vrijeme pisanja ovog rada (15. lipnja 2020.).

100 Tako vidi čl. 162. st. 1. ZAPSP-a o utvrđivanju naknade za korištenje predmeta zaštite, čl. 168. ZAPSP-a o obavještavanju nositelja prava o upravljanju njihovim pravima, čl. 168.b ZAPSP-a o podacima koji se nositeljima i korisnicima prava daju na zahtjev, čl. 168.c ZAPSP-a o podacima koji se javno objavljuju, čl. 168.t ZAPSP-a o zaštiti osobnih podataka, čl. 171.a o suradnji s nadležnim regulatorima u drugim državama članicama te posebno čl. 171.b, 171.c te 171.d ZAPSP-a o nadzoru nad radom neovisnog upravljačkog subjekta. 
Doc. dr. sc. Tomislav Jakšić: Pojam organizacije za kolektivno ostvarivanje prava i neovisnog upravljačkog... Zbornik radova Pravnog fakulteta u Splitu, god. 58, 3/2021, str. 785-814

više sudionika na tržištu kolektivnog ostvarivanja prava pospješuje tržišnu utakmicu, a pruža nositeljima prava i korisnicima potrebnu mogućnost izbora između više organizacija za kolektivno ostvarivanje prava.

Konačno valja upozoriti i na izričaj čl. 216. st. 2. NPZAPSP-a prema kojem prethodno odobrenje za obavljanje takve djelatnosti kolektivnog ostvarivanja prava mora tražiti "osoba koja ima sjedište ili poslovni nastan u Republici Hrvatskoj". Prema čl. 216. st. 3. NPZAPSP-a, "osoba koja ima sjedište ili poslovni nastan u nekoj drugoj državi članici Europske unije", može kolektivno ostvarivati prava u Republici Hrvatskoj kao neovisni upravljački subjekt: 1) ako po pravu države u kojoj ima poslovni nastan može obavljati u toj državi djelatnost kolektivnog ostvarivanja prava te 2) ako o namjeri obavljanja takve djelatnosti u Republici Hrvatskoj prethodno obavijesti Zavod. Prema tome, ovisno o tome tko namjerava obavljati djelatnost kolektivnog ostvarivanja prava kao neovisni upravljački subjekt, zakonodavac predlaže naizgled dva različita načina na koji se stječe mogućnost obavljanja takve djelatnosti u Hrvatskoj: i) model prethodnog odobrenja (st. 2.) te ii) model prethodne obavijesti o namjeri obavljanja djelatnosti kolektivnog ostvarivanja prava (st. 3.). Iako se naizgled te dvije odredbe razlikuju u tome tko namjerava obavljati djelatnost neovisnog upravljačkog subjekta, pokazat će se kako one stvaraju pravnu nesigurnost jer su kontradiktorne i nejasne.

Naime, pravo "poslovnog nastana" nalaže da osoba sa sjedištem izvan Hrvatske (npr. trgovačko društvo sa sjedištem u Njemačkoj) mora u Hrvatskoj ostvariti poslovni nastan (npr. osnivanjem podružnice u Hrvatskoj) ako u njoj namjeravaju trajno obavljati svoju djelatnost. ${ }^{101} \mathrm{~S}$ obzirom na izneseno, prema čl. 216. st. 2. NPZAPSP-a proizlazi kako domaća, ali i strana pravna osoba mora tražiti i dobiti odobrenje DZIV-a za kolektivno ostvarivanje prava na području Hrvatske ako u njoj namjerava "trajno" obavljati djelatnosti neovisnog upravljačkog subjekta. To stoga što takva strana osoba mora zbog namjere "trajnog" obavljanja djelatnosti imati u Hrvatskoj poslovni nastan zbog čega potpada pod primjenu čl. 216. st. 2. NPZAPSP-a, a ne čl. 216. t. 3. ZPZAPSP-a. Shodno tome, nameće se pitanje razgraničenja tih dviju odredaba NPZAPSP-a.

Prema odredbi čl. 216. st. 3. NPZAPSP-a, osoba sa sjedištem ili poslovnim nastanom izvan Hrvatske ne mora tražiti niti dobiti odobrenje od DZIV-a za kolektivno ostvarivanje prava, već o namjeri obavljanja djelatnosti kolektivnog ostvarivanja prava mora samo obavijestiti regulatora. Nejasno je stoga, primjerice, znači li to da neovisni upravljački subjekt sa sjedištem u Njemačkoj mora prvo obavijestiti DZIV prema st. 3., a potom kada ga obavijesti mora i podnijeti zahtjev za dobivanje odobrenja prema st. 2. jer u Hrvatskoj namjerava trajno obavljati djelatnost kolektivnog ostvarivanja prava, a zbog čega osniva podružnicu te time u Hrvatskoj stječe poslovni nastan. Takvo je tumačenje otegotnije za strane osobe jer osim obavještavanja o namjeri obavljanja djelatnosti moraju pribaviti i odobrenje nadležnog regulatora što nema smisla jer se time sadržajno ništa ne

101 Poslovni nastan u Hrvatskoj postiže se, primjerice, osnivanjem podružnice inozemnog trgovačkog društva ili osnivanjem društva kćeri što, s druge strane, potpada pod st. 2. predmetne odredbe. 
postiže. S druge strane, ako se na takvo strano društvo primjenjuje samo st. 2 ., nameće se pitanje svrhovitosti st. 3. Nešto pravno smislenije tumačenje tih odredaba može dovesti do zaključka kako se dio odredbe st. 2. o poslovnom nastanu odnosi samo na pravne osobe koje imaju sjedište u Hrvatskoj ili izvan Europske unije, a namjeravaju u Hrvatskoj obavljati djelatnosti neovisnog upravljačkog subjekta. Ako je tome tako, bilo koja osoba koja namjerava obavljati djelatnost neovisnog upravljačkog subjekta u Hrvatskoj može izbjeći pribavljanje prethodnog odobrenja domaćeg regulatora tako da osnuje društvo sa sjedištem u drugoj državi članici gdje se lako registrira za obavljanje djelatnosti neovisnog upravljačkog subjekta (npr. u Njemačkoj) pa u Hrvatskoj samo obavijesti DZIV o namjeri obavljanja takve djelatnosti. Time izbjegava otegotniji postupak dobivanja odobrenja regulatora za obavljanje djelatnosti neovisnog upravljačkog subjekta. Kako se na taj način može lako izbjeći potreba dobivanja otegotnijeg odobrenja prema čl. 216. st. 2. NPZAPSP-a, postavlja se pitanje čemu uopće onda nametati potrebu pribavljanja takvog odobrenja. Takvim rješenjem domaći zakonodavac samo kažnjava one gospodarstvenike koji bi za obavljanje takve djelatnosti radije osnovali pravnu osobu sa sjedištem u Hrvatskoj. Zbog svega iznesenog proizlazi kako predloženo rješenje nije dovoljno jasno jer adresati ne znaju što im je činiti te se potencijalno prepuštaju diskrecijskoj procjeni i tumačenju nadležnog regulatora oko toga je li potrebno tražiti prethodno odobrenje ili je dovoljno samo dati prethodnu obavijest o namjeri obavljanja djelatnosti na području Hrvatske. Svrha zakonske norme ne smije biti stvaranje takve pravne nesigurnosti, već upravo suprotno. Shodno tome, predlaže se odustati od takvog dvojakog modela te, kao što je prethodno u tekstu predloženo, primijeniti isključivo model prethodne obavijesti o namjeri obavljanja djelatnosti, neovisno o tome je li riječ o domaćoj ili stranoj pravnoj osobi koja želi obavljati djelatnost neovisnog upravljačkog subjekta.

Nejasno je i u čemu se nalaze tzv. "nedostaci u primjeni dosadašnjih propisa" na koje se poziva zakonodavac u obrazloženju ovog prijedloga, očito aludirajući i na promjene vezane za obavljanje djelatnosti neovisnog upravljačkog subjekta. Ako se navedeno pravilo primjenjuje u Njemačkoj koja o tome ima samo jednu odredbu (§91. VGG), koja po svojem smislu u velikoj mjeri odgovara sadržaju čl. 171.b st. 1. ZAPSP-a, nejasno je gdje se u primjeni predmetne norme nailazi na nedostatke $u$ primjeni kao i kakva je narav takvih nedostataka (jesu li nedostaci postupovnopravne ili materijalnopravne naravi). Neuvjerljivo je stajalište da su nedostaci na koje su u primjeni naišli navodni adresati čl. 171.b st. 1. ZAPSP-a od tolikog značaja da nalažu toliku veliku zamjenu sadržaja predmetne odredbe s novim sadržajem iz čl. 216. st. 2. NPZAPSP-a, dok s druge strane, njemački zakonodavac trenutno ne nalazi potrebnim mijenjati slično rješenje iz $§ 91$. VGG-a tj. ne nalazi u primjeni te odredbe takve nedostatke. Takav prijedlog odredaba NPZAPSP-a, ako bude prihvaćen, neće dovesti do veće jasnoće i jednostavnije primjene zakona, već upravo suprotno - tek će pokazati nedostatke u primjeni. Ako se zakonodavac ipak odluči za promjenu postojećeg pravila iz čl. 171.b st. 1. ZAPSP-a, potrebno je jasno odrediti tko mora tražiti odobrenje za obavljanje djelatnosti neovisnog upravljačkog subjekta, a tko mora samo obavijestiti regulatora o namjeri obavljanja takve djelatnosti. 


\section{ZAKLJUČAK}

Kolektivno ostvarivanje prava u Hrvatskoj i mnogim drugim državama članicama moguće je obavljati preko tradicionalne organizacije za kolektivno ostvarivanje prava i preko neovisnog upravljačkog subjekta. Uvođenje neovisnog upravljačkog subjekta u hrvatsko pravo posljedica je usklađivanja hrvatskog prava sa zahtjevima Direktive 2014/26/EU. Neovisni upravljački subjekt, kao alternativa organizaciji za kolektivno ostvarivanje prava, podliježe nižem stupnju nadzora i kontrole od strane nadležnog regulatora jer redovito ostvaruje autorska i srodna prava u manjem opsegu od organizacije za kolektivno ostvarivanje prava. Štoviše, kolektivno ostvarivanje prava od strane neovisnog upravljačkog subjekta usmjereno je redovito na pojedina prava ili određene kategorije predmeta zaštite (npr. djela koja su prikladna za izvođenje kao pozadinska glazba u trgovačkom centru). Takvo ostvarivanje prava pritom redovito počiva na ugovoru koji neovisni upravljački subjekt sklapa s pojedinim nositeljem prava ili osobom koja ga je ovlaštena zastupati. Ulazak neovisnog upravljačkog subjekta na tržište kolektivnog ostvarivanja prava može se smatrati korisnim i dobrodošlim jer potiče tržišno natjecanje na tržištu na kojem su do tada dominirale organizacije za kolektivno ostvarivanje prava.

Kako navedene dvije organizacije potpadaju pod različitu razinu nadzora od strane nadležnog regulatora, a i stoga što je djelatnost takvih organizacija potrebno razgraničiti od djelatnosti drugih subjekata na tržištu koji ostvaruju i iskorištavaju autorska i srodna prava, potrebno je identificirati uvjete koji se pripisuju takvim organizacijama. Budući da obje organizacije obavljaju djelatnost kolektivnog ostvarivanja prava, logično je da se dio takvih uvjeta jednako primjenjuje na obje organizacije. To su opći uvjeti: 1) ostvarivanja autorskih i srodnih prava, 2) kolektivnog ostvarivanja prava za više nositelja prava, 3) ostvarivanja prava za zajedničku korist (račun) nositelja prava te 4) kolektivnog ostvarivanja autorskih i srodnih prava kao jedine ili glavne svrhe takve organizacije. Pored tih uvjeta, organizacija za kolektivno ostvarivanje prava prema ZAPSP-u mora ispuniti i dva posebna uvjeta: 1) pripadnost ili potpadanje pod kontrolu svojih članova te 2) ustrojenost na neprofitnoj osnovi. S druge strane, neovisni upravljački subjekt mora ispuniti također dva dodatna uvjeta: 1) ne smije pripadati u cijelosti niti djelomično članovima, a ne smije biti niti pod njihovom izravnom ili neizravnom kontrolom, 2) a njegovo poslovanje pritom mora biti usmjereno na ostvarivanje dobiti. Upravo su ti posebni uvjeti osnovni kriterij razgraničenja između tih dviju organizacija. Takvi posebni uvjeti, kao i prethodno navedeni opći uvjeti opet su kriterij razgraničenja u odnosu na druge subjekte koji na tržištu ostvaruju i iskorištavaju autorska i srodna prava (npr. nakladnici te menadžeri i agenti nositelja prava). Ako takav subjekt ne ostvaruje barem jedan od navedenih općih i posebnih uvjeta, ne može se kvalificirati kao organizacija za kolektivno ostvarivanje prava niti kao neovisni upravljački subjekt pa samim time niti ne potpada pod kontrolu i nadzor nadležnog regulatora u pogledu obavljanja djelatnosti kolektivnog ostvarivanja prava.

U pogledu nacrta NPZAPSP-a ništa se bitno suštinski ne mijenja u pogledu određenja pojma organizacije za kolektivno ostvarivanje prava i neovisnog 
upravljačkog subjekta u odnosu na određenje iz ZAPSP-a. Stoga se svi prigovori i prijedlozi upućeni u pogledu ZAPSP-a primjenjuju i na NPZAPSP. Pored toga, za razliku od ZAPSP-a, novi prijedlog donosi i novine u obliku zamjetno strožih uvjeta koji se moraju ispuniti kako bi zainteresirana osoba mogla početi obavljati djelatnost kolektivnog ostvarivanja prava kao neovisni upravljački subjekt na području Hrvatske. Dvojbeno je gospodarsko i pravno opravdanje takvog strožeg rješenja, a posebice je dvojbena opravdanost petogodišnje zabrane podnošenja novog zahtjeva za obavljanje djelatnosti kolektivnog ostvarivanja prava.

\section{BIBLIOGRAFIJA}

\section{Pravna književnost}

1. Ahlberg, H., Götting, H., Urheberrecht, UrhG - KUG - VerG - VGG Kommentar, 4. Auflage, München 2018.

2. Alhberg, H., Götting, H., BeckOK Urheberrecht, 24. Auflage, München 2019.

3. Dreier, T., Schulze, G., Urheberschutzgesetz, 6. Auflage, 2018., München 2018.

4. Eichleberger, J., Wirth, T., Seifert, F., Urheberrechtgesetz mit Verwertungsgesselschaftengesetz, Handkommentar, 3. Auflage, BadenBaden 2020.

5. Heine, R., Holzmüller, T., VGG Verwertungsgesselschaftengesetz Kommentar, Leck 2019.

6. Kling, C., Gebietsübergreifende Vergabe von Online-Rechten an Musikwerken, Problemme einer effizienten Lizenzeirungspraxis unter Geltung des VGG, Leck 2018.

7. Gliha, I., "Raspolaganje autorskim pravom (i srodnim pravima)", Zbornik Hrvatskog društva za autorsko pravo, 5 (2004.).

8. Wandtke, A, Bullinger, W., Urheberrecht, UrhG - KUG - VGG - InfoSocRL, Praxiskommentar, 5. Auflage, München 2019.

9. von Lewinski, S., Copyright Throughout the World, Vol. 1.

\section{Hrvatski pravni propisi}

1. Zakon o autorskom pravu i srodnim pravima, Narodne novine br. 167/03, 79/07, 80/11, 125/11, 141/13, 127/14, 62/17, 96/18.

2. Zakon o izmjenama i dopunama Zakona o autorskim i srodnim pravima, Narodne novine br. 62/17.

3. Zakon o obveznim odnosima, Narodne novine br. 35/05, 41/08, 125/11, 78/15, 29/18.

4. Zakon o trgovačkim društvima, Narodne novine br. 111/93, 34/99, 121/99, 52/00, 118/03, 107/07, 146/08, 137/09, 125/11, 152/11, 111/12, 68/13, 110/15, 40/19. 
Doc. dr. sc. Tomislav Jakšić: Pojam organizacije za kolektivno ostvarivanje prava i neovisnog upravljačkog... Zbornik radova Pravnog fakulteta u Splitu, god. 58, 3/2021, str. 785-814

\section{Europski pravni propisi}

1. Direktiva 2014/26/EU od 25. veljače 2014. o kolektivnom ostvarivanju autorskog prava i srodnih prava te izdavanju odobrenja za više državnih područja za prava na internetsko korištenje glazbenih djela na unutarnjem tržištu, SL L 84, 20. III. 2014., str. 72-98.

2. Preporuka Komisije 2005/737/EZ od 18. svibnja 2005. o kolektivnom prekograničnom upravljanju autorskim i srodnim pravima za zakonite internetske glazbene usluge, SL L 276, 21. X. 2005., str. 54-57.

\section{THE MEANING OF THE COLLECTIVE MANAGEMENT ORGANIZATION AND THE INDEPENDENT MANAGEMENT ENTITY}

In order to qualify a legal entity as the collective management organization that persons must: 1) manage copyright or rights related to copyright, 2) manage such rights for more than one rightholder (e.g. author), 3) manage such rights for the collective benefit (on behalf) of rightholders and 4) manage such rights as its sole or main purpose. Besides these general conditions the collective management organization must fulfil two additional unique conditions: 1) belonging to or being under control of its members (rightholders or other authorized persons) and 2) being organized on a non-profit basis. On the other hand, the independent management entity, same as the collective management organization, must fulfil the above mentioned four general conditions but also fulfil two distinct conditions: 1) neither belonging to nor being controlled, directly or indirectly, wholly or in part, by rightholders and 2) being organized on a for-profit basis. The paper analyses these conditions with intent to make a clear distinction between the collective management organization and the independent management entity but to differentiate these organizations from other commercial entities that do not collectively manage such rights. Such distinction is also important to determine the level of supervision that the State Intellectual Property Office is undertaking over these two organizations since each of them falls under the different level of such supervision. Besides these conditions, the paper also analyses the corresponding provisions of the draft of the new proposal of the Copyright and the Related Rights Act.

Key words: collective management of rights, the collective management organization, the independent management entity, copyright, rightholder 